\title{
Spatial distribution of heavy metals and Ecological Risk Assessment for the main sub-branches (Rayahs) sediments of Nile River, Egypt
}

Seliem M. El Sayed

National Institute of Oceanography and Fisheries (NIOF)

Salem G. Salem

National Institute of Oceanography and Fisheries (NIOF)

Mohamed H. Abdo

National Institute of Oceanography and Fisheries (NIOF)

Mohamed H.H. Ali

National Institute of Oceanography and Fisheries (NIOF)

Mohamed E. Goher ( $\nabla$ smgoher@yahoo.com )

National Institute of Oceanography and Fisheries (NIOF)

\section{Research Article}

Keywords: Sediment quality, Rayahs, Nile River, Heavy metals, Pollution indices, Ecological Risk

Posted Date: October 24th, 2022

DOI: https://doi.org/10.21203/rs.3.rs-1247777/v2

License: (c) (i) This work is licensed under a Creative Commons Attribution 4.0 International License. Read Full License 


\section{Abstract}

Sediments act as a sink or source of pollution under various conditions. Moreover, they can serve as pollution indicators. The present research aims to evaluate sediment quality associated with its content in heavy metals and the potential ecological risk, focusing on the sub-branches of Nile River (Rayahs) in Egypt, including El-Tawfiky (RT), El-Menoufy (RM), El-Behary (RB), and El-Nassery (RN). According to the results, El-Rayahs sediments are characterized by an increasing sand fraction, followed by mud. Regarding heavy metals pollution, $\mathrm{Cd}$ registered the highest pollution ranking, whereas $\mathrm{Fe}, \mathrm{Mn}$, $\mathrm{Zn}$, $\mathrm{Pb}$, and $\mathrm{Ni}$ exhibited the lowest effect. Furthermore, the ecological risk for El-Rayahs sediments increases northward; however, most sites either showed slight pollution or did not record any degree of contamination, except the northern stretch of El-Behery (El-Mahmoudia Canal), which is a very high-polluted zone, with high ecological risk according to the contamination degree $\left(\mathrm{C}_{\mathrm{d}}\right)$ and potential ecological risk $(\mathrm{RI})$ indices.

\section{Introduction}

Sediments are regarded as active substances and dynamic systems, that contain minerals, rocks, sand, and waste of dead animals and plants; they act as a reservoir for organic matter and various pollutants (Goher et al., 2014; Bremner, 2021). Sediments are transported together with heavy elements via adhesion or absorption (Qu et al., 2017). Sediments are also habitat to benthic algae, and invertebrates. Geochemical components and minerals in sediments can indicate the properties, distributions, and sources of pollutants and provide information regarding changes in the aquatic environment and local human activity history (Lan et al., 2011; Yuana et al., 2019). Sediment quality is evaluated by comparing levels of estimated parameters to the regional baseline, historical, and predevelopment (RAMP, 2021). Sediment pollution can occur either directly within water bodies or through transportation by wind, effluents discharge, or rain, carrying heavy elements into the watercourse (Paul, 2017). Heavy metals (HMs), related to human, and/or natural activities, are present in the Earth's environment. HMs pollution is the result of industrialization and urbanization; it is also caused by irrigation water (Ali et al., 2019). Because of their persistence, environmental toxicity, and bioaccumulation, HMs are a major source of pollution in aquatic environments (Huang et al., 2020). In general, water pollution by HMs has become a severe environmental issue in both developing and developed countries because of the progress of civilization, urbanization, and industrialization, leading to the discharge of massive amounts of untreated wastes into the aquatic ecosystem (UNCSD, 2010; Arefin, 2016; Goher et al., 2019). According to Mateo-Sagasta et al., (2017), irrigation water represents about $70 \%$ of water abstractions worldwide, making agricultural wastes an important source of contamination of the aquatic environment (Goher et al., 2019). Further, more than $80 \%$ of the global municipal wastewater is flowing into watercourses without treatment, as set by WWAP (2017).

In watercourses and riverine systems, HMs are considerably more concentrated in sediments than in the water body, and most HMs immediately deposit after entering rivers (Shyleshchandran et al., 2018). Under suitable hydrological and chemical conditions, HMs can be released into the water column, causing the watercourses pollution and affecting the health of aquatic organisms (Kouidri et al., 2016). Furthermore, HMs accumulation in sediments directly affects the benthic creatures, as well as other organisms through the food web (Fu et al., 2014; Huang et al., 2020). Therefore, it is of great importance to study the distribution and levels of HMs in sediments of rivers, waterways, and all water bodies, in addition to assessing the potential environmental risk of HMs.

The Nile River represents the soul of Egyptians, providing them approximately $95 \%$ of freshwater used by them. Weathering of the rocks of the Ethiopian Highlands led to the enrichment of sediments of the Nile River with elements such as Fe, Mn, Cu, Cr, and Ni (Elnazer et al., 2018; Mostafa et al., 2019). After constructing the High Dam in Aswan, the largest portion of these metals is deposited in the southern part of Nasser Lake (Imam et al., 2020; Goher et al., 2021). However, as a result of the increase in population and industrial enhancement, Nile receives huge amounts of different wastes, inorganic and organic pollutants, and HMs through its traveling into the Mediterranean Sea through Sudan and Egypt (Goher et al., 2019, 2021). At El-Delta Barrage in Egypt, Nile bifurcates into two main branches, Damietta and Rosetta, and four other canals or sub-branches (called Rayah). The four Rayahs, from east to west, are ElTawfiky (RT), El-Menoufy (RM), El-Behary (RB), and El-Nassery (RN) (Goher, 2015; Talab et al., 2016; Goher et al., 2021). Rayahs, in addition to Rosetta and Damietta branches, provide freshwater for various purposes to approximately 40 million capita in the Delta region and Alexandria Governorate (Goher, 2015).

The aim of this study is to evaluate the sediment quality of the Rayahs and El-Mahmoudia and El-Nubaria Canals, in terms of HMs content and the effect of environmental conditions on their distribution pattern. Ecological risk indices were used to study sediment pollution using different assessment approaches.

\section{Material And Methods Study Area}

After traveling for approximately $950 \mathrm{~km}$ from Aswan in the south to Cairo in the north, Nile River bifurcates in two branches, Rosetta and Damietta, at 1.5-km southern El-Kanatier El-Khyeria, where RM, RB, and RN originate from the former and RT originates from the latter (Fig. 1). El-Rayahs are characterized by the existence of several water treatment (most are small stations), electric power plants, and villages, Ezzabs (small villages), and small towns, heavily scattered on both sides. The El-Rayahs' lengths extend from approximately $180 \mathrm{~km}$ (RM) to $215 \mathrm{~km}$ (RB), with an average width of $40-50 \mathrm{~m}$ and an average depth of 2$5 \mathrm{~m}$. The water levels in all El-Rayahs decrease downstream; therefore, they are replenished again with water from Damietta (RT and RM), Rosetta (RB), and RB $(\mathrm{RN})$. A severe shortage of water and a noticeable drop in water level occurs at the end of these Rayahs, except for RN, which is an important navigable stream.

RT arises from Damietta branch and extends into the middle and eastern part of the Delta, heading north, parallel to some extent with Damietta branch until Mansoura City at T5, where it branches into two parts: the first is heading north to Damietta City, and is characterized by a lack of water and narrow width; almost all water disappears at Faraskour City, thus water samples are not collected from this branch. The second, which is characterized by abundant water respect to the first, runs eastward within Dakahlia Governorate, across Dekerness, El-Gamalia, and El-Manzalah cities. In the past, this branch flowed into Manzalah Lake. Before station T5, the El-Rayah is refilled with freshwater from the Damietta branch. 
RM starts from Rosetta branch at El-Kanater El-Khayria City and extends into the middle part of the Delta, thus breaking El-Menoufia, El-Dakahlia, and ElGharbia Governorates, then heading north to Gamasa City and the southern part of Burullus Lake; this Rayah has a high number of minor branches, particularly in the El-Menoufia Governorate. At Zifta City (upstream of site M5), a connected canal bearing large quantities of water from Damietta branch discharges water into RM, to increase the water level, which decreases gradually again.

RB originates from Rosetta branch at El-Kanater El- Khayria City and stretches into the western part of the Delta in a NW direction, parallel to the Rosetta branch and west of Giza Governorate through Nikla, Abu-Ghalib, and El-Khatatba cities. Next, it passes Beheira Governorate through Kafr-Daoud, KomHamada, Itai El-Baroud, Damanhur, Kafr El-Dawar cities, and Alexandria Governorate. Notably, RB crosses with El-Mahmoudia Canal after Damanhur City (ElMahmoudia Canal originates from Rosetta branch at El-Mahmoudia City). This segment (from sites B6-B9) flows northwest until Alexandria, where it is named El-Mahmoudia Canal.

RN begins from Rosetta branch at El-Kanater El- Khayria City and runs in the western part of the Delta, parallel to RB, where it flows northwest toward the Noubaria Canal that originates from RB. RN joins El-Nubaria Canal, near Kanater Pauline (at Koum Hamada), before traveling northwest across Mariout Lake, to end at the Mediterranean Sea. The segment from sites N4 to N8 is named El-Nubaria Canal.

\section{Sampling}

A total of 31 surface sediment samples (including 7 from RT, 7 from RM, 9 from RB, and 8 from RN) were collected in late 2017 (Table 1 ). Samples were sealed in airtight polythene bags as promptly as possible. Hence, sediments were dried in drying Oven at $105^{\circ} \mathrm{C}$ to a consistent weight and were ground using a mortar and pestle. Later, samples were sieved to $<120 \mu \mathrm{m}$. 
Details and description of the selected sites of the study area

\begin{tabular}{|c|c|c|c|c|c|}
\hline Site & Name & Latitude & Longitude & $\begin{array}{l}\text { Distance } \\
(\mathbf{k m})^{\star}\end{array}$ & Description \\
\hline T1 & El Kanater & $30^{\circ} 11^{\prime} 46.58 "$ & $31^{\circ} 7^{\prime} 55.98^{\prime \prime}$ & $1-1.5$ & /very fast water /receives few wastewater \\
\hline T2 & Banha & $30^{\circ} 28 ' 24.0^{\prime \prime}$ & $31^{\circ} 12^{\prime} 1.04^{\prime \prime}$ & 35 & opposite of Benha water plant /residential region in the two sides \\
\hline Т3 & Met-Ghamr & $30^{\circ} 41^{\prime} 35.3^{\prime \prime}$ & $31^{\circ} 16^{\prime} 50.2^{\prime \prime}$ & 65 & $\begin{array}{l}\text { It flows Between agricultural and residential regions beside the agricultural way } \\
\text { (Cairo-El-Mansoura)/ }\end{array}$ \\
\hline T4 & Agga & $30^{\circ} 54^{\prime} 23.12 "$ & $31^{\circ} 16 ' 51.88^{\prime \prime}$ & 90 & It flows Between agricultural and residential regions in the two sides \\
\hline T5 & Mansoura & $31^{\circ} 04^{\prime} 02.84^{\prime \prime}$ & $31^{\circ} 25^{\prime} 02.13^{\prime \prime}$ & 115 & Before branching of El-Rayah/ Between agricultural and residential regions \\
\hline T6 & Dekerness & $31^{\circ} 5^{\prime} 38.65^{\prime \prime}$ & $31^{\circ} 37^{\prime} 37.77^{\prime \prime}$ & 130 & $\begin{array}{l}\text { Residential region in the west side and agricultural region in east side/low water } \\
\text { level }\end{array}$ \\
\hline T7 & El-Manzalah & $31^{\circ} 09^{\prime} 49.9^{\prime \prime}$ & $31^{\circ} 56^{\prime} 09.5^{\prime \prime}$ & 170 & Static water/ receives a lot of wastes \\
\hline M1 & El Kanater & $30^{\circ} 11^{\prime} 59.85^{\prime \prime}$ & $31^{\circ} 6^{\prime} 44.97^{\prime \prime}$ & 1 & Downstream the Delta Barrage/receives few wastewater \\
\hline M2 & El-Khadra & $30^{\circ} 20^{\prime} 15^{\prime \prime}$ & $31^{\circ} 02^{\prime} 55^{\prime \prime}$ & 30 & It is between agricultural and residential regions \\
\hline M3 & $\begin{array}{l}\text { Shebeen El- } \\
\text { Koum }\end{array}$ & $30^{\circ} 32 ' 04.3^{\prime \prime}$ & $31^{\circ} 00^{\prime} 48.3^{\prime \prime}$ & 60 & It is between agricultural and residential regions \\
\hline M4 & El-Santa & $30^{\circ} 43^{\prime} 44.50^{\prime \prime}$ & $31^{\circ} 7^{\prime} 28.88^{\prime \prime}$ & 85 & Receives large amount of wastewater with slow water current \\
\hline M5 & Zifta & $30^{\circ} 47^{\prime} 26.15^{\prime \prime}$ & $31^{\circ} 9^{\prime} 16.12 "$ & 95 & Downstream the replenishing with water from Damietta branch \\
\hline M6 & El-Mahalla & $30^{\circ} 56^{\prime} 59.4^{\prime \prime}$ & $31^{\circ} 09^{\prime} 21.4^{\prime \prime}$ & 115 & Between residential regions / receives few wastewater \\
\hline M7 & Belqas & $31^{\circ} 07^{\prime} 59.9^{\prime \prime}$ & $31^{\circ} 22^{\prime} 50.1^{\prime \prime}$ & 155 & Between agricultural regions \\
\hline B1 & El Kanater & $30^{\circ} 10^{\prime} 47.36^{\prime \prime}$ & $31^{\circ} 6^{\prime} 18.69^{\prime \prime}$ & $3-4$ & It runs between agricultural and industrial regions / receives few wastewater \\
\hline B2 & Abo ghaleb & $30^{\circ} 14^{\prime} 46.90^{\prime \prime}$ & $30^{\circ} 56^{\prime} 33.68 "$ & 30 & Downstream Abu-ghaleb electrical plant/ agricultural region in east side \\
\hline B3 & Kafr Dawood & $30^{\circ} 27^{\prime} 3.75^{\prime \prime}$ & $30^{\circ} 49^{\prime} 41.35^{\prime \prime}$ & 60 & It flows between agricultural and residential regions \\
\hline B4 & El-Tawfikia & $30^{\circ} 48^{\prime} 36.91^{\prime \prime}$ & $30^{\circ} 45^{\prime} 21.65^{\prime \prime}$ & 100 & at El-Tawfikia bridge/ beside agricultural way (Cairo-Alexandria) \\
\hline B5 & Damanhour 1 & $31^{\circ} 00^{\prime} 46.5^{\prime \prime}$ & $30^{\circ} 28^{\prime} 52.8^{\prime \prime}$ & 135 & At the entrance of Damanhour city \\
\hline B6 & 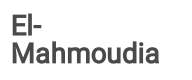 & $31^{\circ} 10^{\prime} 25.9^{\prime \prime}$ & $30^{\circ} 31^{\prime} 42.1^{\prime \prime}$ & 145 & $1 \mathrm{Km}$ downstream the originate of El-Mahmoudia Canal from the Rosetta branch \\
\hline B7 & Damanhour 2 & $31^{\circ} 5^{\prime} 16.85^{\prime \prime}$ & $30^{\circ} 25^{\prime} 16.79 "$ & 140 & $\begin{array}{l}\text { Downstream the confluence of RB with El-Mahamoudia /Middle of a crowded } \\
\text { residential region }\end{array}$ \\
\hline B8 & $\begin{array}{l}\text { Kaffr El- } \\
\text { dawar }\end{array}$ & $31^{\circ} 7^{\prime} 31.58 "$ & $30^{\circ} 13^{\prime} 31.82^{\prime \prime}$ & 170 & Between agricultural and residential regions at the two sides/Low water level \\
\hline B9 & El-Siuof & $31^{\circ} 13^{\prime} 6.67^{\prime \prime}$ & $29^{\circ} 59^{\prime} 39.74^{\prime \prime}$ & 205 & $\begin{array}{l}\text { Upstream the end of El-Rayah/ Next to many of water and electricity plants/Low } \\
\text { water level }\end{array}$ \\
\hline N1 & El Kanater & $30^{\circ} 10^{\prime} 36.78^{\prime \prime}$ & $31^{\circ} 6 ' 29.77^{\prime \prime}$ & 2 & Between residential regions \\
\hline N2 & El-Khatatba & $30^{\circ} 19^{\prime} 57.76^{\prime \prime}$ & $30^{\circ} 48^{\prime} 57.5^{\prime \prime}$ & 40 & Between agricultural and residential regions \\
\hline N3 & $\begin{array}{l}\text { Koum } \\
\text { Hamada }\end{array}$ & $30^{\circ} 30^{\prime} 31.3^{\prime \prime}$ & $30^{\circ} 48^{\prime} 18.6^{\prime \prime}$ & 70 & $\begin{array}{l}\text { Located before the confluence of El-Rayah with El-Nubaria Canal / surrounded by } \\
\text { agricultural regions }\end{array}$ \\
\hline N4 & El-Noubaria 1 & $30^{\circ} 42^{\prime} 51.0^{\prime \prime}$ & $30^{\circ} 44^{\prime} 26.8^{\prime \prime}$ & 93 & The beginning of El-Nubaria Canal / very fast water flow \\
\hline N5 & El-Noubaria 2 & $30^{\circ} 43^{\prime} 44.69^{\prime \prime}$ & $30^{\circ} 33^{\prime} 47.14^{\prime \prime}$ & 90 & $\begin{array}{l}\text { It receives wastes of Kom Hamada electricity plant/ downstream meeting of El- } \\
\text { Rayah with El-Nubaria Canal }\end{array}$ \\
\hline N6 & Itai El-Baroud & $30^{\circ} 49^{\prime} 4.75^{\prime \prime}$ & $30^{\circ} 14^{\prime} 57.56^{\prime \prime}$ & 115 & Between agricultural and residential regions \\
\hline N7 & Housh-Issa & $30^{\circ} 54^{\prime} 38.06^{\prime \prime}$ & $30^{\circ} 2 ' 9.52^{\prime \prime}$ & 140 & Between agricultural and residential regions \\
\hline N8 & El-Haouies & $30^{\circ} 59^{\prime} 54.76^{\prime \prime}$ & $29^{\circ} 51^{\prime} 49.97^{\prime \prime}$ & 190 & Before El-Nubaria current lock (El-Haouies) \\
\hline
\end{tabular}

\section{* Distance downstream of the Delta Barrage}

\section{Procedures}

Grain size analysis and sediment textural classes were performed according to (Folk, 1980). Methods by (Griffiths, 1951) and (Carver, 1971) were used to analyze samples with $>5 \%$ fine fraction (finer than $4 \varnothing$ ). Organic matter (OM) was determined by loss on ignition (Hanna, 1965). 
As described by (Goher et al., 2021), microwave digestion of sediments was performed according to the USEPA 3052 method (USEPA, 1996a). The studied metals (Fe, Mn, Zn, Cu Cr, Ni, Pb, and Cd) were analyzed using inductively-coupled argon plasma atomic absorption (ICP 6500 Duo, Thermo Scientific,

\section{England).}

\section{Pollution index}

Seven pollution indices were used to assess the ecological risk of the four Rayahs sediments, including contamination factor (CF), contamination degree ( $\mathrm{C}_{\mathrm{d}}$ ), pollution load index (PLI), ecological risk factor (Er), potential ecological risk index (RI), enrichment factor (EF), and index of geo-accumulation (Igeo). CF, Er, EF, and Igeo are single indices, whereas $\mathrm{C}_{\mathrm{d}}, \mathrm{PLI}$, and RI represent integrated indices (Table 2).

In the present study, average shale values (ASVs), reported by (Turekian \& Wedepohl, 1961), were used as a reference level of HMs, instead of background values. ASVs of the studied metals are $46700,950,95,40,20,68,90$, and $0.3 \mu \mathrm{g} / \mathrm{g}$ for Fe, $\mathrm{Mn}, \mathrm{Zn}, \mathrm{Cu}, \mathrm{Pb}$. $\mathrm{Ni}$, Cr, and Cd, respectively.

Table 2

Pollution classes of indices used.

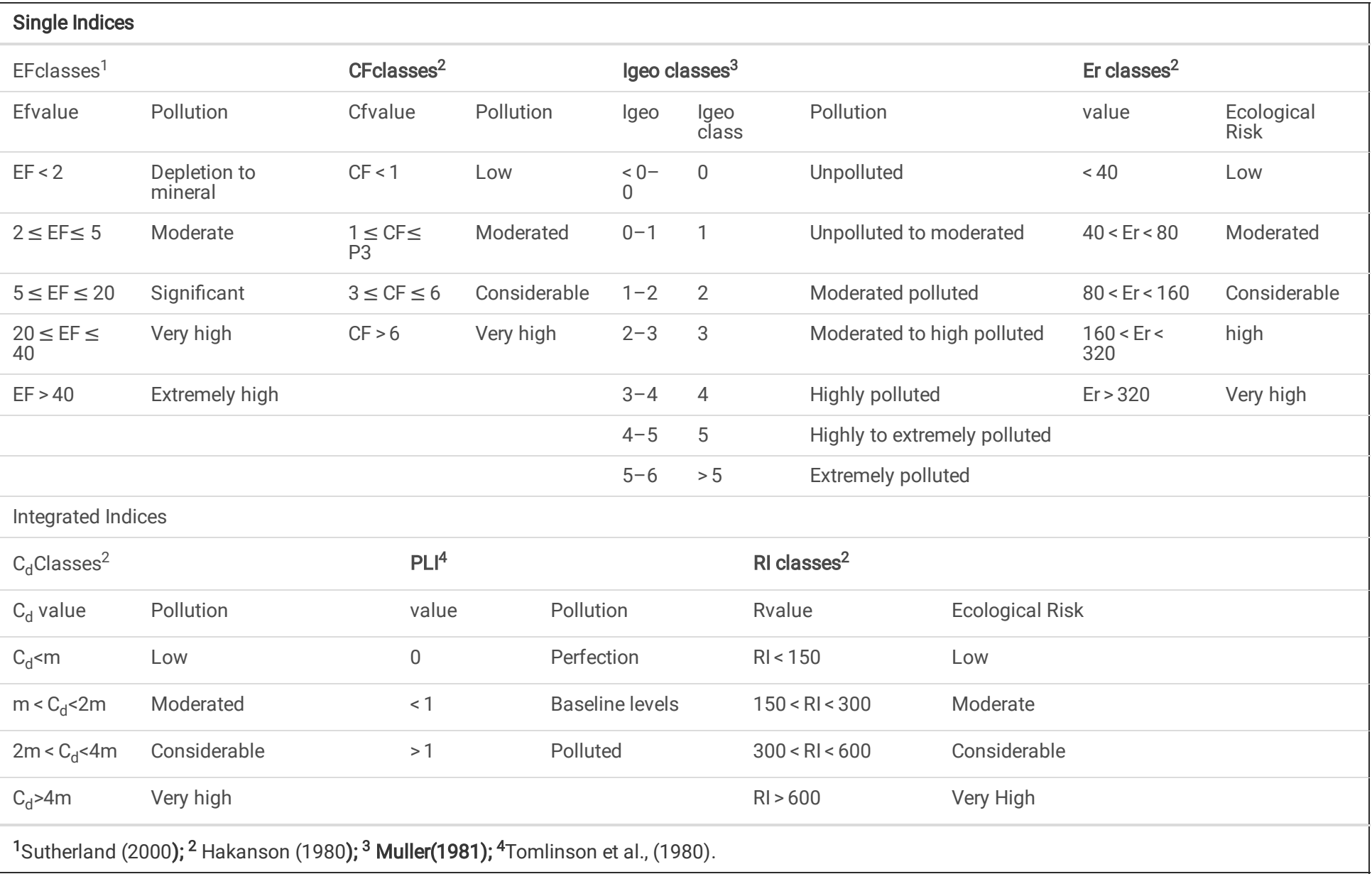

\section{Contamination factor}

The level of contamination of sediments by given toxic substances (metals), suggested by (Hakanson, 1980), is expressed in terms of a contamination factor (CF) and is calculated as

\section{CF = metal content in the sediment/background level of metal. (1) Contamination degree}

The degree of contamination $\left(\mathrm{C}_{d}\right)$ was originally defined as the sum of all contamination factors: $\left(\mathrm{C}_{d}\right)=\sum \mathrm{CF}(2)$.

\section{The pollution load index}

Tomlinson et al., (1980) proposed the pollution load index (PLI). PLI for a single site is the $\mathrm{n}^{\text {th }}$ root of the product of $\mathrm{n}$ CF values, according to the following formula:

\section{PLI for a site $=n$th $\sqrt{ } \mathrm{CF}_{1} * \mathrm{CF}_{2} * . . \mathrm{F}_{\mathrm{n}}(3)$}


where $n$ equals the number of sites.

\section{Ecological risk factor and Potential ecological risk}

An ecological risk factor (Er) is a numerical expression of a contaminant's potential ecological risk:

$\mathrm{Er}=\mathrm{T} * \mathrm{CF},(5)$

where $\mathrm{T}$ is the toxic response factor for a specific substance and $\mathrm{CF}$ is the contamination factor. T equals 1 for $\mathrm{Fe}, \mathrm{Mn}$, and $\mathrm{Zn} ; 2$ for $\mathrm{Cr} ; 5$ for $\mathrm{Cu}, \mathrm{Pb}$, and $\mathrm{Ni}$; and 30 for Cd (Hakanson, 1980). In the same context, the potential ecological risk (RI), which is defined as the sum of risk factor

$\mathrm{RI}=\sum \operatorname{Er}(6)$

Enrichment factor

The EF is a commonly used method for determining enrichment ratios and the degree of anthropogenic pollution (Zakir et al., 2008):

$\left.\left.\left.E F=\left[C_{M} / C_{X}\right)_{\text {sample }} /\right) C_{M} / C_{X}\right)_{\text {Earth's crust }}\right](7)$

where $\mathrm{C}_{\mathrm{M}}$ is the concentration of the analyzed metal and $\mathrm{C}_{\mathrm{X}}$ is the concentration of the immobile element, such as $\mathrm{Al}, \mathrm{Fe}, \mathrm{Ti}, \mathrm{Mn}, \mathrm{Li}, \mathrm{Sc}$, or $\mathrm{Zr}$ (Blaser et al., 2000; Liu et al., 2005; Chatterjee et al., 2007; Zhang et al., 2007; Goher et al., 2014; Tiomo et al., 2021).

\section{Geo-accumulation index}

The geo-accumulation index ( $\mathrm{I}_{\text {geo }}$ ) values are calculated for the studied metals introduced by Muller (1981), as follows:

$I_{\text {geo }}=\log _{2}\left[C_{n} /\left(1.5 * b_{n}\right)\right](8)$

where $C_{n}$ is the content of analyzed element $(n)$ in the sample and $b_{n}$ is the geochemical background.

\section{Results And Discussion}

\section{Grain size, moisture, and organic matter analysis}

Sediment fractions, moisture, and organic matter (OM) contents of the Rayahs sediment are given in Table 3. Sand was the dominant fraction, varying in the ranges of $42.79 \%-73.84 \%, 27.73 \%-87.77 \%, 36.74 \%-82.23 \%$, and $19.23 \%-84.20 \%$ in RT, RM, RB, and RN, respectively (Table 3 and Fig. 2). Sand was deposited through erosion of two banks and by wind (aeolian deposits, with fine to very-fine sand) with limited water movement. RB and RT were characterized by low sand deposition compared to RN and RM. Sand fraction exhibits a strong negative correlation with mud $(r=-78)$, moisture \% $(r=-53 ; p=0.01)$, and Fe $(r=-$ $0.4 ; P<0.05)$. This is related to silt and fine-grained clays that reflect sedimentation during commonly-occurring perennial water flows and coarse-grained clastic layers in between this clay matrix; therefore, they reflect a very high energy environment, or flood events (Raja et al., 2018).

By contrast, the main gravel fractions were in the range of $0.5 \%-47.24 \%, 0.26 \%-12.40 \%, 2.56 \%-24.01 \%$, and $1.7 \%-20.59 \%$ in RT, RM, RB, and RN, respectively, with an order of RT > RB > RN > RM. (Table 3 and Fig. 2). Notably, gravel fraction comprised mollusca shells and fragments associated with granules deposited by banks erosion and some gravel $>2 \mathrm{~mm}$ was transported to sub-branches by human activity at banks.

Mud fraction is the second dominant after sand in the ranges of $9.97 \%-48.11 \%$ (average $28.39 \%$ ) for RT, $9.72 \%-65.43 \%$ (average $36.62 \%$ ) for RM, $12.38 \%-46.36 \%$ (average of $28.98 \%$ ) for RB, and $6.53 \%-60.17 \%$ (average $28.79 \%$ ) for RN. Rate of mud deposition increased northward, related to the decrease of water movement. Mud (silt and clay) was deposited via water (river deposit) and wind (aeolian deposits) from the two banks. The results agreed with those obtained by Abu El-Enain et al., (1997); Abd El-Monsif (2009); Salem and Lotfy (2017); Goher et al., (2021), who stated that the dominant fractions of Nile River are sand $>$ mud (silt and clay) > gravel. We can state that the distribution of grain size depends on the depth and energy of water movement, where mud (clay and silt) increased with depth and quite water with slow currents, while sand and gravel increased at banks with low depth and high movement water. After the establishment of the Aswan High Dam in 1964, great changes in the hydrological system in the Nile Delta led to a halt in the arrival of sediments and floodwaters to the Mediterranean Sea. The sources of sediments in the Nile River are the shore erosion and aeolian sedimentation (Stanley et al., 2004; Hamouda et al., 2014; Ghoneim et al., 2015; Elsherif et al., 2020; Goher et al., 2021). Mud exhibits a strong positive correlation with moisture \% $(r=0.73$, $\mathrm{n}=31$; $p<0.01)$ and $\mathrm{OM} \%(r=0.043 ; \mathrm{n}=31 ; \mathrm{p}<0.05)$; this can be related to the fermentation process, which is conducted through the sinking of dead microorganisms forming organic matter (Dinakaran \& Krishnayya, 2011; Farahat, 2019).

$\mathrm{OM}$ in sediments is the remains of organic life, fossils in the geological sense (Welte, 1696). Numerous indicators, or proxies, can be derived from the OM composition of sediments and used to reconstruct the paleoenvironments of water bodies and their watersheds (Dianto et al., 2020). Regarding the obtained results, the horizontal distribution of OM is shown in Table 3 and Fig. 3. OM contents in the Rayahs sediments were found in the order of RN $<$ RB $<$ RM $<$ RT, with mean values of $8.12 \%, 8.55 \%, 10.57 \%$, and $11.17 \%$, respectively (Table 3 and Fig. 3 ). We found that OM percentage increases with mud fraction with respect to sand and gravel fractions, which is consistent with the results obtained by Salem, (2011); Goher et al., (2021). Results showed the increase of the $\mathrm{OM}$ in RM and RT with respect to RB and RN, which may be related to the high population, and thus, human activity, in the first two Rayahs. OM showed a strong positive correlation with moisture $\%(r=0.5 ; \mathrm{n}=31 ; p<0.01)$ that may be explained by the high porosity of mud, which stores $\mathrm{OM}$ and water.

Water content is one of the most important indicator properties used to establish a correlation between sediment behavior and its indicator properties. Moisture percentage has been defined as the ability of sediment to save water. Moisture contents in sediments varied in the ranges of $40.23 \%-64.98 \%$,

Page 6/20 
38.93\%-72.30\%, 38.91\%-63.42\%, and 36.53\%-71.28\% in RT, RM, RB, and RN, respectively (Table 3 and Fig. 3). RM Sediment has a higher moisture content followed by RN, whereas RT and RB show low values.

Table (3): Texture and heavy metal contents in the four Rayahs sediments.

\begin{tabular}{|c|c|c|c|c|c|c|c|c|c|c|c|c|c|c|c|}
\hline \multirow[t]{2}{*}{ parameter } & \multicolumn{4}{|c|}{ El-Tawfiky } & \multicolumn{4}{|c|}{ El-Menoufy } & \multicolumn{4}{|c|}{ El-Behary } & \multicolumn{3}{|c|}{ El-Nassery } \\
\hline & Min & Max & $A v$ & $\mathrm{Sd}$ & Min & Max & Av & $\mathrm{Sd}$ & Min & Max & Av & $\mathrm{Sd}$ & Min & Max & $A v$ \\
\hline Gravel & 0.57 & 47.24 & 15.01 & $\stackrel{ \pm}{17.4}$ & 0.26 & 12.40 & 5.09 & $\stackrel{ \pm}{4.69}$ & 2.56 & 24.01 & 9.93 & $\stackrel{ \pm}{6.64}$ & 1.70 & 20.59 & 9.09 \\
\hline Sand & 42.79 & 73.84 & 56.62 & $\stackrel{ \pm}{9.7}$ & 27.73 & 87.77 & 56.64 & $\stackrel{ \pm}{19.4}$ & 36.74 & 82.24 & 60.86 & $\stackrel{ \pm}{15.1}$ & 19.24 & 84.20 & 62.11 \\
\hline Mud & 9.97 & 48.11 & 28.39 & $\stackrel{ \pm}{14.2}$ & 9.72 & 65.43 & 36.62 & $\stackrel{ \pm}{19.5}$ & 12.38 & 46.36 & 28.98 & $\stackrel{ \pm}{13.0}$ & 6.53 & 60.17 & 28.79 \\
\hline Mo\% & 40.23 & 64.98 & 49.65 & $\stackrel{ \pm}{9.27}$ & 38.93 & 72.30 & 54.68 & $\stackrel{ \pm}{12.1}$ & 38.91 & 63.42 & 49.92 & $\stackrel{\mathbf{\pm}}{8.81}$ & 36.53 & 71.28 & 52.97 \\
\hline $0 . M \%$ & 5.87 & 16.47 & 11.17 & $\begin{array}{l} \pm \\
4.12\end{array}$ & 6.82 & 15.75 & 10.57 & $\stackrel{ \pm}{3.38}$ & 4.48 & 14.15 & 8.55 & $\stackrel{ \pm}{3.51}$ & 4.78 & 14.08 & 8.12 \\
\hline $\mathrm{Fe} \mathrm{mg} / \mathrm{g}$ & 6.75 & 6.75 & 10.51 & $\stackrel{ \pm}{2.62}$ & 7.91 & 13.61 & 10.42 & $\stackrel{ \pm}{2.10}$ & 7.12 & 14.90 & 10.58 & $\stackrel{ \pm}{2.95}$ & 7.36 & 12.13 & 9.69 \\
\hline $\mathrm{Mn} \mu \mathrm{g} / \mathrm{g}$ & 123.2 & 201.8 & 153.85 & $\stackrel{ \pm}{25.9}$ & 177.2 & 252.0 & 199.83 & $\stackrel{ \pm}{26.1}$ & 239.14 & 422.50 & 316.07 & $\stackrel{ \pm}{66.6}$ & 165.29 & 245.96 & 198.69 \\
\hline $\mathrm{Zn} \mu \mathrm{g} / \mathrm{g}$ & 16.38 & 36.36 & 23.75 & $\stackrel{ \pm}{7.33}$ & 20.80 & 41.66 & 29.33 & $\stackrel{ \pm}{7.09}$ & 7.12 & 109.56 & 82.50 & $\stackrel{ \pm}{16.6}$ & 26.33 & 48.93 & 39.08 \\
\hline $\mathrm{Cu} \mu \mathrm{g} / \mathrm{g}$ & 4.96 & 12.68 & 8.76 & $\stackrel{ \pm}{2.46}$ & 9.51 & 16.51 & 12.57 & $\stackrel{ \pm}{2}_{2.39}$ & 20.02 & 40.05 & 28.39 & $\stackrel{\mathbf{t}}{7.18}$ & 14.68 & 23.66 & 18.47 \\
\hline $\mathrm{Pb} \mu \mathrm{g} / \mathrm{g}$ & 4.82 & 12.90 & 7.81 & $\stackrel{ \pm}{2.49}$ & 7.06 & 15.90 & 10.20 & $\stackrel{ \pm}{3.29}$ & 8.14 & 27.54 & 15.61 & $\stackrel{ \pm}{7.90}$ & 8.11 & 18.60 & 12.43 \\
\hline $\mathrm{Ni} \mu \mathrm{g} / \mathrm{g}$ & 3.22 & 5.62 & 4.07 & $\begin{array}{l} \pm \\
0.87\end{array}$ & 3.08 & 6.78 & 4.38 & $\stackrel{ \pm}{1.20}$ & 2.38 & 8.54 & 4.83 & $\stackrel{ \pm}{2.23}$ & 2.63 & 8.57 & 5.10 \\
\hline $\mathrm{Cr} \mu \mathrm{g} / \mathrm{g}$ & 3.35 & 8.79 & 5.98 & $\stackrel{ \pm}{1.70}$ & 6.28 & 11.08 & 7.84 & $\stackrel{ \pm}{1.57}$ & 10.70 & 33.50 & 21.03 & $\stackrel{ \pm}{7.79}$ & 6.61 & 16.54 & 11.62 \\
\hline $\mathrm{Cd} \mu \mathrm{g} / \mathrm{g}$ & 0.42 & 1.27 & 0.703 & $\begin{array}{l} \pm \\
0.28\end{array}$ & 0.72 & 1.14 & 0.91 & $\begin{array}{l}\mathbf{\pm} \\
0.18\end{array}$ & 0.785 & 3.07 & 1.62 & $\begin{array}{l} \pm \\
0.84\end{array}$ & 0.722 & 1.39 & 1.09 \\
\hline
\end{tabular}

\section{Heavy Metals}

Sediment contamination poses one of the worst environmental threats in ecosystems, which act as sinks and sources of contaminants in aquatic systems; thus, sediment analysis is critical for assessing the pollution status of the environment (Mucha et al., 2003). Geochemical analyses of Fe, Mn, $\mathrm{Zn}, \mathrm{Pb}, \mathrm{Cu}, \mathrm{Ni}$, $\mathrm{Cr}$, and $\mathrm{Cd}$ were conducted, and their concentrations are listed in Table 3 and represented in Fig. 4.

Iron $(\mathrm{Fe})$ is one of the major constituents of the lithosphere; it is critical in the behavior of several trace elements and is located in the intermediate position between macro and micronutrients in plants, animals, and humans (Kabata-Pendias \& Arun, 2007). The sediment content in Fe is controlled by several factors, including the distance from the outfall, nature of sediment, OM content, oxidation/reduction conditions, TDS levels (salinity), and pH value of water (Masoud et al., 2011; Goher et al., 2021). Concerning our results, the lowest $(6.75 \mathrm{mg} / \mathrm{g})$ and the highest $(15.17 \mathrm{mg} / \mathrm{g})$ values of Fe were recorded in RT at sites T1 and T7, respectively, which is consistent with the results obtained by Goher et al., (2021), who worked in River Nile. However, our results are lower than those regarding Ismailia Canal, Rosetta branch, and Greater Cairo, obtained by El Sayed (2015); El-Amier et al., (2015); Lasheen and Ammar (2009). Fe exhibits a strong positive correlation ( $\mathrm{n}=31 ; p<0.01)$ with $\mathrm{Mn}(r=0.47), \mathrm{Pb}(r=0.72), \mathrm{Ni}(r=0.67), \mathrm{Cr}(r=0.47)$, and $\mathrm{Cd}(r=0.69)$ and is positively correlated ( $\mathrm{n}=31 ; p<$ $0.05)$ with $\mathrm{Zn}(r=0.36)$ and $\mathrm{Cu}(r=0.40)$, indicating the common source and association of metals with oxy-hydroxides of Fe-Mn, which is also supported by Imam et al., (2020); Goher et al., (2021). Furthermore, the positive correlation of Fe with OM $(r=40, \mathrm{n}=31$; $p<0.05)$ indicates the association of Fe deposition with $\mathrm{OM}$ accumulation in the sediment.

Manganese ( $\mathrm{Mn}$ ) exists in sediments principally as $\mathrm{MnO}_{2}$, which is very insoluble in water under reducing conditions: Mn in the dioxide form is reduced from valence 4 to 2 , and solubility occurs as with ferric oxide (Ahmed et al., 2019). Mn shows irregular distribution patterns in all Rayahs sediments; the lowest value $(123.16 \mu \mathrm{g} / \mathrm{g})$ has been found in RT and the maximum $(422.5 \mu \mathrm{g} / \mathrm{g})$ in RB, with a major difference between sites. This result was lower than that obtained in previous studies in Greater Cairo (Lasheen and Ammar 2009), Rosetta branch (El Bouraie et al., 2010), and Nasser Lake (Imam et al., 2020). The strong positive correlation ( $\mathrm{n}=31 ; p<0.01)$ of Mn with $\mathrm{Zn}(r=0.95), \mathrm{Cu}(r=0.95), \mathrm{Pb}(r=0.84), \mathrm{Ni}(r=0.57), \mathrm{Cr}(r=0.96)$, and Cd $(r=0.89)$ indicates that it probably represents the geochemical support phases of these metals, associated with Mn coprecipitate, adsorbed on Mn oxides, or hydroxide (Ottosen et al., 2006).

Zinc (Zn) may occur in sediments as carbonate, oxide, and sulfide (AIP, 2017; Imam et al., 2020); its concentration is mainly attributed to the input of organic wastes in aquatic environments, which come from municipal sewage and dumping materials, in addition to industrial discharges, sewage effluent, and runoff 
sources (Alagarsamy, 2006; Goher et al., 2015). In the present study, Zn content ranged between $16.38 \mu \mathrm{g} / \mathrm{g}$ (in RT) and 109.56 $\mu \mathrm{g} / \mathrm{g}$ (in RB), with a high spatial significant difference $(p<0.01)$ based on ANOVA data. These findings may be related to the anthropogenic at the ends of the rayahs especially in RB. The obtained results were lower than the corresponding values found in River Nile (102.2-261 $\mu \mathrm{g} / \mathrm{g})$ (Abdel-Satar, 2005), Damietta branch (75.5-888.5 $\mu \mathrm{g} / \mathrm{g}$ ) (Goher, 1998), and Upper Egypt (1-271 $\mu \mathrm{g} / \mathrm{g}$, with an average of $114 \mu \mathrm{g} / \mathrm{g})$ (El-Kammar et al., 2009). However, values were higher than that recorded in Nasser Lake (11.55-82.71 $\mu \mathrm{g} / \mathrm{g}$ ) (Imam et al., 2020) and close to the values ranging from 10 to $145.95 \mu \mathrm{g} / \mathrm{g}$ in Ismailia Canal, obtained by El Sayed (2015) and in Greater Cairo (Lasheen and Ammar 2009). Zn exhibits a strong positive correlation ( $\mathrm{n}=31 ; p<0.01)$ with $\mathrm{Cu}(r=0.95), \mathrm{Pb}(r=0.74), \mathrm{Cr}(r=0.92), \mathrm{Cd}(r=0.82)$, and $\mathrm{Ni}(r=0.43, \mathrm{n}=31 ; p<0.05)$.

\section{Figure (4): Box plot of the studied trace metals in the sediment of the four Rayahs.}

Copper $(\mathrm{Cu})$ is a micronutrient element fundamental to all forms of life. In excessive amounts, it may become toxic to organisms by inducing a reduction in enzymes activity or a random rearrangement of structural proteins (Goldman, 2009; Karak et al., 2017; Goher et al., 2019). The high Cu concentrations in ElRayahs sediments may be attributed to the high accumulation of OM and Fe-Mn oxy-hydroxides produce simultaneous accumulation of HMs in sediments (Ottosen et al., 2006). The highest value $(40.05 \mu \mathrm{g} / \mathrm{g})$ of Cu was recorded in RB and the lowest $(4.96 \mu \mathrm{g} / \mathrm{g})$ in RT, with considerable difference between locations. The obtained results were lower than the corresponding values in River Nile (average, 42 $\mu \mathrm{g} / \mathrm{g}$ ) (El-Kammar et al., 2009) and Greater Cairo 27-90 $\mu \mathrm{g} / \mathrm{g}$ (Lasheen \& Ammar 2009). However, values were close to those (1.0-40.3 $\mu \mathrm{g} / \mathrm{g})$ obtained by Imam et al., (2020) for Nasser Lake. Cu exhibits a strong positive correlation $(\mathrm{n}=31 ; \mathrm{p}<0.01)$ with $\mathrm{Pb}(r=0.84), \mathrm{Cr}(r=0.97), \mathrm{Cd}(r=0.88)$, and $\mathrm{Ni}(r=0.56)$; these results are consistent with the several studies (Goher et al., 2014; El Sayed, 2015; Goher et al., 2021; Abou El-Anwar et al., 2021), who reported that the deposition of Cu and Zn is enhanced by the association of metals with clay minerals or the adsorption of both elements on hydrated iron and manganese oxides. These authors also added that the order of adsorption of most mobile metals fraction is Fe/Mn oxides $>0 \mathrm{M}>$ clay.

Lead $(\mathrm{Pb})$ is considered as one of the most toxic elements to humans and animals, and its toxicity is largely dependent on its solubility (Wani et al., 2015); the form of $\mathrm{PbSO}_{4}$ is much soluble than $\mathrm{PbCO}_{3}$ and has a greater toxicity, whereas $\mathrm{PbS}$ has a very low solubility and toxicity (Lide, 2008; SCDHEC, 2020). Pb enters the aquatic environment throughout precipitation of dust fall out, leaching soil, and industrial wastes discharge (Abd El-Aal 2020). $\mathrm{Pb}$ contents varied in the range of $4.82-27.54 \mu \mathrm{g} / \mathrm{g}$ in RT and RB, respectively; this result is consistent with the results obtained by (Mostafa et al., 2019) for River Nile and (Goher et al., 2014) for Nasser Lake, whereas they are higher than those obtained by Lasheen and Ammar (2009) for Nile River in Greater Cairo (2.33-7.5 $\mu \mathrm{g} / \mathrm{g}$ ) and lower than those of Upper Egypt (average, $10 \mu \mathrm{g} / \mathrm{g}$ ) obtained by El-Kammar et al., (2009). Pb has a strong positive correlation ( $\mathrm{n}=31 ; p<0.01)$ with $\mathrm{Ni}(r=$ $0.84), \operatorname{Cr}(r=0.87)$, and $\mathrm{Cd}(r=0.95)$.

Nickel often was considered an essential nutrient for animals. Now, Ni is generally not classified an essential element for humans and higher animals (Nielsen, 2021). Oppositely, $\mathrm{Ni}$ is possibly harmful and poisonous to aquatic organisms and is listed in the priority elements for the water quality field within the European Union of Water Framework Directive (Szarek-Gwiazda et al., 2011). In general, the pentlandite is the primary nickel source. Ni may be found in basalt, sandstone, slate, and clay minerals. It accumulates in sediments and is a part of various biological cycles. Nickel may enter lakes, rivers, and streams from non-point and point sources, such as emissions of metal industries, waste incinerators, and power plants. Moreover, Ni is directly discharged to water bodies from various industries (Lenntech, 2022).

In the present study, the maximum $(8.57 \mu \mathrm{g} / \mathrm{g})$ and minimum $(2.38 \mu \mathrm{g} / \mathrm{g})$ values of Ni were recorded at RN and RB, respectively; they are lower than the range of $59-65 \mu \mathrm{g} / \mathrm{g}$ found for Greater Cairo by Lasheen and Ammar (2009), from the value of $28.56 \mu \mathrm{g} / \mathrm{g}$ obtained by El Sayed (2015) for Ismailia Canal, and the range of $5.2-40 \mathrm{\mu g} / \mathrm{g}$ obtained by Goher et al., (2021) for River Nile. Ni has a strong positive correlation $(\mathrm{n}=31 ; p<0.01)$ with $\mathrm{Cr}(r=0.61)$ and $\mathrm{Cd}(r=0.73)$.

Chromium ( $\mathrm{Cr}$ ) is a transition metal, found in water in oxidation states, ranging from $\mathrm{Cr}^{+6}$ to $\mathrm{Cr}^{-}$; it is a nonessential element and is classified as a toxic metal, entering watercourses through both anthropogenic and natural sources, such as geogenic processes and interaction of microbes with mafic and ultramafic rocks, in addition to industrial activities, such as production of energy, chemicals, and metals manufacturing. Furthermore, different wastes release Cr compounds into the aquatic environment (Tumolo et al., 2020). Concerning our results, the highest value of $\mathrm{Cr}(33.5 \mu \mathrm{g} / \mathrm{g}$ ) was recorded at RB, whereas the lowest $(3.45 \mu \mathrm{g} / \mathrm{g})$ was recorded at RT with highly significant difference between sites. These values are lower than $185.6 \mu \mathrm{g} / \mathrm{g}$, obtained by El Bourie et al., (2010) for Rosetta branch and higher than the range of 0-8.5 $\mu \mathrm{g} / \mathrm{g}$, obtained by Goher et al., (2021) along the River Nile, from Aswan to Cairo. On the contrary, our results are close to the $36.6-46 \mu \mathrm{g} / \mathrm{g}$ range found for Greater Cairo by Lasheen and Ammar (2009). Chromium has a strong positive correlation with Cd ( $r$ $=0.91, n=31, p<0.01)$.

Cadmium (Cd) precipitates as $\mathrm{CdCO}_{3}$ coprecipitation, which is similar to lead (Imam et al., 2020; Goher et al., 2021). Its content showed a maximum level $(3.066 \mu \mathrm{g} / \mathrm{g})$ at RB, whereas the lowest $(0.421 \mu \mathrm{g} / \mathrm{g})$ was recorded at RT, with highly significant difference between sites; these results were lower than the

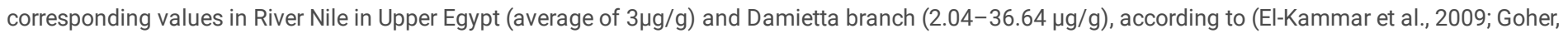
1998), respectively. However, our values are close to the ranges of $0.1-4.3 \mu \mathrm{g} / \mathrm{g}$ and $1.7-3 \mu \mathrm{g} / \mathrm{g}$, obtained by Lasheen and Ammar (2009) in Greater Cairo and El Sayed (2015) for Ismailia Canal, respectively.

Notably, the maximum values for most metals, based on mean values, have been found at RB (except for nickel at RN), whereas minimum values (on average) were recorded at RT. Furthermore, the increase of HMs in the northward sediments among all Rayahs is attributed to the impact of human activities along their sides. The data of Pearson's correlation coefficients between the measured metals with Fe and $\mathrm{Mn}(r=0.47-0.98, \mathrm{n}=31, p<0.01)$ revealed the role of steeling of Fe and $\mathrm{Mn}$ oxides in the deposition of metals into the sediment. In the same context, the positive correlation of metals with organic matter demonstrated the relation between $\mathrm{OM}$ accumulation and the distribution of $\mathrm{HMs}$ in sediments. The present study confirmed that the order of deposition of most metals is associated with Fe and Mn oxides > OM > clay, which is consistent with the results obtained by Ottosen et al., (2006); El-Kammar et al., (2009); Goher et al., (2014); Goher et al., (2021); Abou El-Anwar et al., (2021). 


\section{Ecological risk indices}

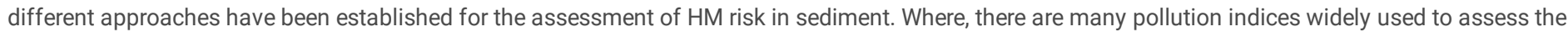

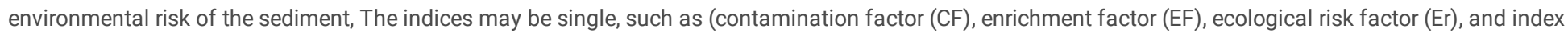

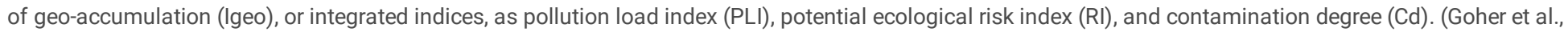

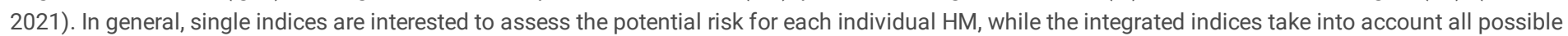

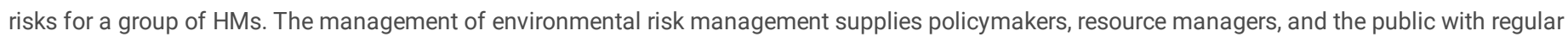
methods that enable informed decision-making (Goher et al., 2014).

\section{Contamination factor}

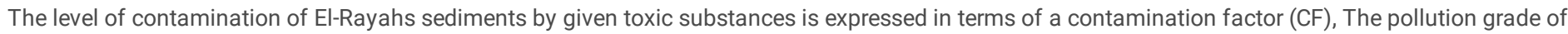

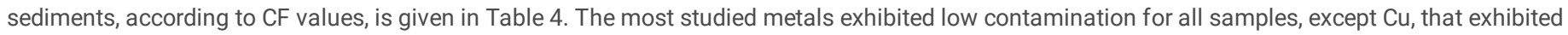

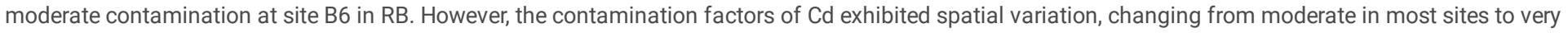
high at site $\mathrm{B} 6$ in RB.

\section{Contamination degree}

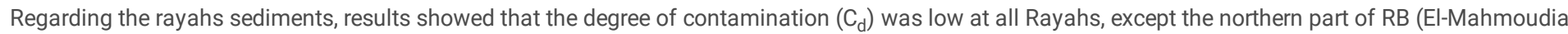
Canal), which was very-highly contaminated (Table 4).

\section{The pollution load index}

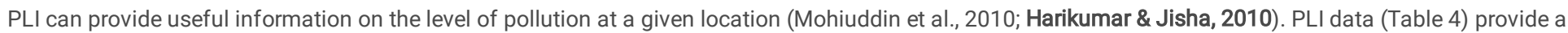

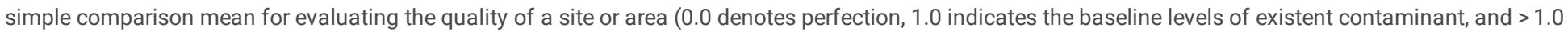

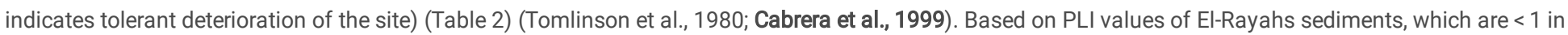
all examined sites, they are categorized as not significantly polluted.

Table (4): Contamination factor, Degree of Contamination (Cd) and Pollution Load Index (PLI) of the studied trace metals of the four Rayahs sediments. 


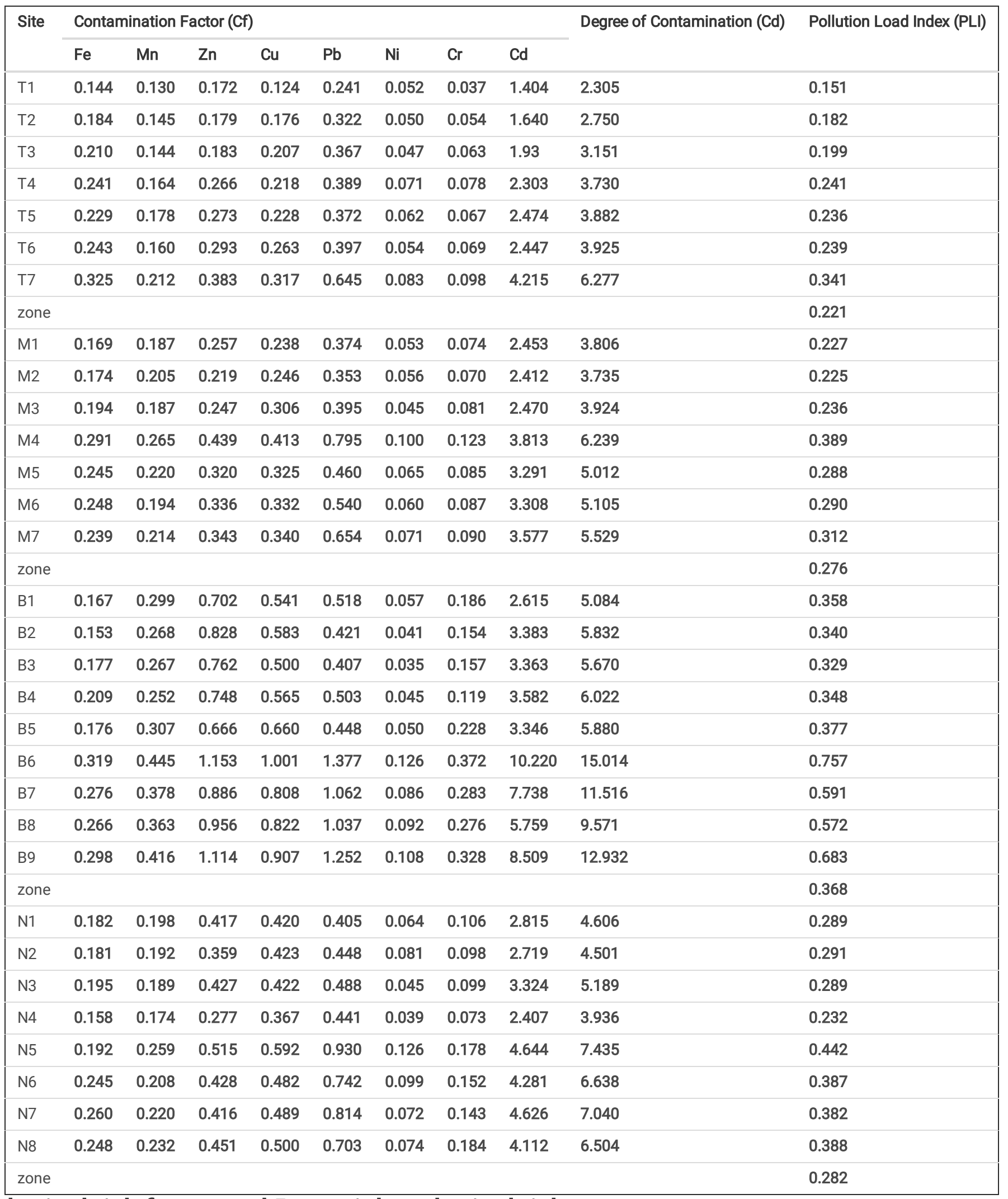

\section{Ecological risk factor and Potential ecological risk}

Er values of El-Rayahs sediments showed that all sites have a low ecological risk for all analyzed metals, except Cd that showed moderate to considerable risk at RT, RM, and RN, with a noticeable increase northward; a high ecological risk exists in RB especially, at the northern segment (El-Mahmoudia Canal) (Table 5). In the same context, the potential ecological risk (RI) showed a low ecological risk for all Rayahs except the north of RB, which had a high ecological risk (Table 5).

Table (5): Ecological Risk Factor (Er), Potential Ecological Risk Index (RI) of the studied trace metals of the four Rayahs sediments. 


\begin{tabular}{|c|c|c|c|c|c|c|c|c|c|}
\hline \multirow[t]{2}{*}{ Site } & \multicolumn{8}{|c|}{ Ecological Risk Factor (Er) } & \multirow[t]{2}{*}{ Potential Ecological Risk Index (RI) } \\
\hline & $\mathrm{Fe}$ & Mn & $\mathrm{Zn}$ & $\mathrm{Cu}$ & $\mathrm{Pb}$ & $\mathrm{Ni}$ & $\mathrm{Cr}$ & Cd & \\
\hline T1 & 0.144 & 0.130 & 0.172 & 0.620 & 1.204 & 0.262 & 0.074 & 42.125 & 44.73 \\
\hline T2 & 0.184 & 0.145 & 0.179 & 0.880 & 1.609 & 0.252 & 0.107 & 49.185 & 52.54 \\
\hline T3 & 0.210 & 0.144 & 0.183 & 1.034 & 1.833 & 0.237 & 0.126 & 57.910 & 61.68 \\
\hline $\mathrm{T} 4$ & 0.241 & 0.164 & 0.266 & 1.091 & 1.945 & 0.353 & 0.156 & 69.100 & 73.32 \\
\hline T5 & 0.229 & 0.178 & 0.273 & 1.140 & 1.859 & 0.309 & 0.134 & 74.208 & 78.33 \\
\hline T6 & 0.243 & 0.160 & 0.293 & 1.313 & 1.985 & 0.269 & 0.137 & 73.405 & 77.80 \\
\hline T7 & 0.325 & 0.212 & 0.383 & 1.585 & 3.226 & 0.413 & 0.195 & 126.450 & 132.79 \\
\hline M1 & 0.169 & 0.187 & 0.257 & 1.189 & 1.871 & 0.265 & 0.148 & 73.600 & 77.69 \\
\hline M2 & 0.174 & 0.205 & 0.219 & 1.231 & 1.764 & 0.282 & 0.140 & 72.350 & 76.37 \\
\hline M3 & 0.194 & 0.187 & 0.247 & 1.528 & 1.973 & 0.227 & 0.162 & 74.100 & 78.62 \\
\hline M4 & 0.291 & 0.265 & 0.439 & 2.064 & 3.976 & 0.499 & 0.246 & 114.400 & 122.18 \\
\hline M5 & 0.245 & 0.220 & 0.320 & 1.626 & 2.301 & 0.327 & 0.169 & 98.725 & 103.93 \\
\hline M6 & 0.248 & 0.194 & 0.336 & 1.662 & 2.702 & 0.301 & 0.174 & 99.225 & 104.84 \\
\hline M7 & 0.239 & 0.214 & 0.343 & 1.701 & 3.271 & 0.356 & 0.180 & 107.300 & 113.61 \\
\hline B1 & 0.167 & 0.299 & 0.702 & 2.706 & 2.588 & 0.283 & 0.371 & 78.450 & 85.57 \\
\hline B2 & 0.153 & 0.268 & 0.828 & 2.916 & 2.105 & 0.207 & 0.309 & 101.500 & 108.29 \\
\hline B3 & 0.177 & 0.267 & 0.762 & 2.502 & 2.035 & 0.175 & 0.315 & 100.880 & 107.11 \\
\hline B4 & 0.209 & 0.252 & 0.748 & 2.824 & 2.515 & 0.224 & 0.238 & 107.450 & 114.46 \\
\hline B5 & 0.176 & 0.307 & 0.666 & 3.299 & 2.241 & 0.249 & 0.455 & 100.375 & 107.77 \\
\hline B6 & 0.319 & 0.445 & 1.153 & 5.006 & 6.886 & 0.628 & 0.745 & 306.621 & 321.80 \\
\hline B7 & 0.276 & 0.378 & 0.886 & 4.038 & 5.310 & 0.430 & 0.565 & 232.140 & 244.02 \\
\hline B8 & 0.266 & 0.363 & 0.956 & 4.111 & 5.186 & 0.458 & 0.553 & 172.778 & 184.67 \\
\hline B9 & 0.298 & 0.416 & 1.114 & 4.536 & 6.258 & 0.542 & 0.656 & 255.275 & 269.10 \\
\hline N1 & 0.182 & 0.198 & 0.417 & 2.099 & 2.026 & 0.319 & 0.211 & 84.443 & 89.89 \\
\hline N2 & 0.181 & 0.192 & 0.359 & 2.116 & 2.238 & 0.405 & 0.197 & 81.575 & 87.26 \\
\hline N3 & 0.195 & 0.189 & 0.427 & 2.108 & 2.438 & 0.225 & 0.198 & 99.725 & 105.51 \\
\hline N4 & 0.158 & 0.174 & 0.277 & 1.835 & 2.207 & 0.194 & 0.147 & 72.200 & 77.19 \\
\hline N5 & 0.192 & 0.259 & 0.515 & 2.958 & 4.651 & 0.630 & 0.356 & 139.325 & 148.88 \\
\hline N6 & 0.245 & 0.208 & 0.428 & 2.410 & 3.709 & 0.495 & 0.304 & 128.425 & 136.23 \\
\hline N7 & 0.260 & 0.220 & 0.416 & 2.445 & 4.071 & 0.360 & 0.286 & 138.775 & 146.83 \\
\hline N8 & 0.248 & 0.232 & 0.451 & 2.502 & 3.516 & 0.371 & 0.368 & 123.350 & 131.04 \\
\hline
\end{tabular}

\section{Enrichment factor}

The enrichment factor (EF) is a widely used measure for assessing the relative increase of metal compared to average natural abundance because of human activity. In the present study, Fe has been selected as the immobile element. Furthermore, ASVs levels are used as background concentrations; several authors indicated the degree of metal pollution with metal levels according to average shale (Muller, 1969; Forstner \& Muller, 1973; Goher et al., 2014; Goher et al., 2021; Nasir et al., 2021).

According to Table 2, four contamination groups are commonly diagnosed based on the enrichment factor (Sutherland, 2000): EF > 1 indicates high metal content in the sample relative to its level in the Earth's crust. In contrast, EF values $>5$ define sediments as polluted (Atgin et al., 2000). According to Zhang and Liu (2002), EF values between 0.5 and 1.5 suggest that the source of metals in sediments is because of crustal materials or natural processes, whereas EF values > 1.5 indicate an anthropogenic effect. Based on the above considerations, values of $\mathrm{EF}$ of $\mathrm{Ni}$, $\mathrm{Cr}$, and $\mathrm{Mn}$ did not cause remarkable contamination in the El-Rayahs sediments; however, $\mathrm{Cu}$ and $\mathrm{Zn}$ in RB and RN, and Pb in all Rayahs, except RT, showed moderate contamination. Only Cd showed high EF values, indicating significant to very high enrichment at all El-Rayahs, signifying the anthropogenic source of Cd (Table 6).

Table (6): Enrichment Factor (EF) of the studied trace metals of the four Rayahs sediments. 


\begin{tabular}{|c|c|c|c|c|c|c|c|c|}
\hline \multirow[t]{2}{*}{ Site } & \multicolumn{8}{|c|}{ Enrichment Factor (EF) } \\
\hline & $\mathrm{Fe}$ & Mn & $\mathrm{Zn}$ & $\mathrm{Cu}$ & $\mathrm{Pb}$ & $\mathrm{Ni}$ & $\mathrm{Cr}$ & Cd \\
\hline T1 & & 0.897 & 1.193 & 0.858 & 1.668 & 0.362 & 0.258 & 9.721 \\
\hline T2 & & 0.789 & 0.973 & 0.955 & 1.746 & 0.273 & 0.29 & 8.894 \\
\hline T3 & & 0.687 & 0.875 & 0.986 & 1.747 & 0.226 & 0.3 & 9.204 \\
\hline T4 & & 0.678 & 1.103 & 0.904 & 1.612 & 0.292 & 0.323 & 9.545 \\
\hline T5 & & 0.78 & 1.194 & 0.998 & 1.626 & 0.27 & 0.294 & 10.82 \\
\hline T6 & & 0.661 & 1.208 & 1.083 & 1.637 & 0.222 & 0.283 & 10.09 \\
\hline T7 & & 0.654 & 1.178 & 0.976 & 1.986 & 0.254 & 0.3 & 12.98 \\
\hline M1 & & 1.101 & 1.519 & 1.403 & 2.208 & 0.313 & 0.437 & 14.48 \\
\hline M2 & & 1.177 & 1.255 & 1.412 & 2.023 & 0.323 & 0.4 & 13.83 \\
\hline M3 & & 0.962 & 1.271 & 1.574 & 2.033 & 0.233 & 0.417 & 12.72 \\
\hline M4 & & 0.91 & 1.505 & 1.417 & 2.729 & 0.342 & 0.422 & 13.09 \\
\hline M5 & & 0.896 & 1.306 & 1.325 & 1.875 & 0.266 & 0.344 & 13.41 \\
\hline M6 & & 0.785 & 1.355 & 1.342 & 2.181 & 0.243 & 0.352 & 13.35 \\
\hline M7 & & 0.897 & 1.434 & 1.422 & 2.735 & 0.297 & 0.377 & 14.95 \\
\hline B1 & & 1.794 & 4.206 & 3.243 & 3.102 & 0.339 & 1.113 & 15.67 \\
\hline B2 & & 1.755 & 5.432 & 3.824 & 2.76 & 0.271 & 1.012 & 22.18 \\
\hline B3 & & 1.509 & 4.3 & 2.822 & 2.295 & 0.197 & 0.887 & 18.96 \\
\hline B4 & & 1.207 & 3.589 & 2.708 & 2.412 & 0.215 & 0.57 & 17.18 \\
\hline B5 & & 1.744 & 3.791 & 3.754 & 2.55 & 0.284 & 1.295 & 19.03 \\
\hline B6 & & 1.394 & 3.615 & 3.138 & 4.316 & 0.394 & 1.167 & 32.03 \\
\hline B7 & & 1.366 & 3.205 & 2.922 & 3.843 & 0.311 & 1.023 & 28 \\
\hline B8 & & 1.367 & 3.601 & 3.097 & 3.906 & 0.345 & 1.041 & 21.69 \\
\hline B9 & & 1.398 & 3.739 & 3.046 & 4.203 & 0.364 & 1.101 & 28.57 \\
\hline N1 & & 1.09 & 2.292 & 2.31 & 2.23 & 0.351 & 0.581 & 15.49 \\
\hline N2 & & 1.061 & 1.983 & 2.336 & 2.472 & 0.447 & 0.543 & 15.02 \\
\hline N3 & & 0.97 & 2.191 & 2.161 & 2.499 & 0.23 & 0.508 & 17.04 \\
\hline N4 & & 1.104 & 1.758 & 2.328 & 2.8 & 0.246 & 0.466 & 15.27 \\
\hline N5 & & 1.352 & 2.689 & 3.089 & 4.857 & 0.658 & 0.928 & 24.25 \\
\hline N6 & & 0.849 & 1.744 & 1.964 & 3.022 & 0.403 & 0.619 & 17.44 \\
\hline N7 & & 0.848 & 1.603 & 1.883 & 3.136 & 0.278 & 0.551 & 17.82 \\
\hline N8 & & 0.938 & 1.821 & 2.02 & 2.839 & 0.299 & 0.742 & 16.6 \\
\hline
\end{tabular}

\section{Geo-accumulation index}

Muller (1981) proposed seven grades (or classes) of the geo-accumulation index (Table 2). According to the I Ieo of the analyzed metals (Table 7), El-Rayahs sediments are classified as unpolluted for all metals at all sites, except $\mathrm{Cd}$, which exhibited moderate pollution in most sites, with a remarkable enrichment northward, particularly in RB.

Table (7): Index Geo-Accumulation ( geo ) of the studied trace metals of the four Rayahs sediments. 


\begin{tabular}{|c|c|c|c|c|c|c|c|c|}
\hline \multirow[t]{2}{*}{ Site } & \multicolumn{8}{|c|}{ Index Geo-Accumulation (I geo } \\
\hline & $\mathrm{Fe}$ & $M n$ & $\mathrm{Zn}$ & $\mathrm{Cu}$ & $\mathrm{Pb}$ & $\mathrm{Ni}$ & $\mathrm{Cr}$ & $\mathrm{Cd}$ \\
\hline T1 & -3.38 & -3.53 & -3.12 & -3.597 & -2.64 & -4.84 & -5.33 & -0.1 \\
\hline T2 & -3.02 & -3.37 & -3.06 & -3.091 & -2.22 & -4.9 & -4.81 & 0.128 \\
\hline T3 & -2.84 & -3.38 & -3.03 & -2.859 & -2.03 & -4.98 & -4.57 & 0.364 \\
\hline T4 & -2.64 & -3.2 & -2.49 & -2.781 & -1.95 & -4.41 & -4.26 & 0.619 \\
\hline T5 & -2.71 & -3.07 & -2.46 & -2.717 & -2.01 & -4.6 & -4.48 & 0.722 \\
\hline T6 & -2.63 & -3.23 & -2.36 & -2.514 & -1.92 & -4.8 & -4.45 & 0.706 \\
\hline T7 & -2.21 & -2.82 & -1.97 & -2.242 & -1.22 & -4.18 & -3.94 & 1.491 \\
\hline M1 & -3.15 & -3.01 & -2.54 & -2.657 & -2 & -4.82 & -4.34 & 0.71 \\
\hline M2 & -3.1 & -2.87 & -2.78 & -2.607 & -2.09 & -4.73 & -4.43 & 0.685 \\
\hline M3 & -2.95 & -3.01 & -2.6 & -2.296 & -1.93 & -5.05 & -4.21 & 0.72 \\
\hline M4 & -2.36 & -2.5 & -1.77 & -1.861 & -0.92 & -3.91 & -3.61 & 1.346 \\
\hline M5 & -2.61 & -2.77 & -2.23 & -2.206 & -1.7 & -4.52 & -4.15 & 1.133 \\
\hline M6 & -2.6 & -2.95 & -2.16 & -2.174 & -1.47 & -4.64 & -4.1 & 1.141 \\
\hline M7 & -2.65 & -2.81 & -2.13 & -2.141 & -1.2 & -4.4 & -4.06 & 1.254 \\
\hline B1 & -3.17 & -2.33 & -1.1 & -1.471 & -1.54 & -4.73 & -3.01 & 0.802 \\
\hline B2 & -3.3 & -2.49 & -0.86 & -1.363 & -1.83 & -5.18 & -3.28 & 1.173 \\
\hline B3 & -3.08 & -2.49 & -0.98 & -1.584 & -1.88 & -5.42 & -3.25 & 1.165 \\
\hline B4 & -2.85 & -2.58 & -1 & -1.409 & -1.58 & -5.07 & -3.66 & 1.256 \\
\hline B5 & -3.09 & -2.29 & -1.17 & -1.185 & -1.74 & -4.91 & -2.72 & 1.157 \\
\hline B6 & -2.23 & -1.75 & -0.38 & -0.583 & -0.12 & -3.58 & -2.01 & 2.768 \\
\hline B7 & -2.44 & -1.99 & -0.76 & -0.893 & -0.5 & -4.12 & -2.41 & 2.367 \\
\hline B8 & -2.5 & -2.05 & -0.65 & -0.867 & -0.53 & -4.03 & -2.44 & 1.941 \\
\hline B9 & -2.33 & -1.85 & -0.43 & -0.725 & -0.26 & -3.79 & -2.19 & 2.504 \\
\hline N1 & -3.05 & -2.92 & -1.85 & -1.837 & -1.89 & -4.56 & -3.83 & 0.908 \\
\hline N2 & -3.05 & -2.97 & -2.06 & -1.826 & -1.74 & -4.21 & -3.93 & 0.858 \\
\hline N3 & -2.94 & -2.99 & -1.81 & -1.831 & -1.62 & -5.06 & -3.92 & 1.148 \\
\hline N4 & -3.25 & -3.11 & -2.44 & -2.031 & -1.76 & -5.28 & -4.35 & 0.682 \\
\hline N5 & -2.97 & -2.53 & -1.54 & -1.342 & -0.69 & -3.57 & -3.08 & 1.63 \\
\hline N6 & -2.61 & -2.85 & -1.81 & -1.638 & -1.02 & -3.92 & -3.3 & 1.513 \\
\hline N7 & -2.53 & -2.77 & -1.85 & -1.617 & -0.88 & -4.38 & -3.39 & 1.625 \\
\hline N8 & -2.6 & -2.69 & -1.73 & -1.584 & -1.09 & -4.34 & -3.03 & 1.455 \\
\hline
\end{tabular}

Notably, based on different indices data, Cd represented the source of higher environmental risk in all El-Rayahs sediments, which is consistent with (Goher et al., 2021) for sediments of the Nile River from Aswan to Cairo. However, our results differ from (Abou El-Anwar, 2019), who indicated that Zn, Ni, Cr, and Cd are the most possible sources of pollution in sediments of Nile in Upper Egypt.

\section{Sediment quality guidelines}

In recent years, the effect of contaminated sediments on sediment-dwelling organisms (such as invertebrates and plants), aquatic-dependent wildlife (such as mammals, birds, fish, reptiles, and amphibians), and human health has become more intelligible. There are three levels of potential toxic effect on benthic creatures that depend on the continuous, long-term impact of pollutants: the first is "no effect levels," at which no hazardous effect on aquatic creatures has been documented and where no biomagnification via food chain is anticipated; the second is the "lowest effect level," which denotes a level of sediment pollution that the majority of benthic organisms can tolerate or at which the levels of contaminant exhibit a low possible risk effect; the third is the "severe effect level," which denotes the levels of pollutant that has a high potential effect and may harm the majority of benthic species. Moreover, the sedimentdwelling community is likely to be significantly disrupted. 
There are different approaches for the sediment quality guidelines set by several authors and organizations (Persaud et al., 1993; Smith et al., 1996; Long \& Morgan, 1991; USEPA, 1996b, 1997; SLC/MENVIQ, 1992). In the present study, the screening level concentration approach (SLCA), recommended by (Persaud et al., 1993) for the lowest effect level (LEL) and severe effect level (SEL), is used to assess the quality of El-Rayahs sediments and the potential risk of HMs on benthic organisms. Table 8 shows that $\mathrm{Fe}, \mathrm{Mn}, \mathrm{Zn}, \mathrm{Ni}$, and $\mathrm{Pb}$ were below their LEL levels: thus, they did not have any adverse effect on benthic organisms in all El-Rayahs. However, Cd exceeded LEL in 47\% of RT and all other sites, confirming that Cd has the greatest toxic effect on benthic creatures. Furthermore, Cu exceeded LEL and showed adverse effect in $14.3 \%, 100 \%$, and $75 \%$, in RM, RB, and RN samples, respectively, whereas Cr recorded values above its LEL in $100 \%$ of RB samples.

\begin{tabular}{|c|c|c|c|c|c|c|c|c|c|c|}
\hline \multicolumn{3}{|c|}{ Metal } & & \multirow{2}{*}{$\begin{array}{l}\mathrm{Cr} \\
26\end{array}$} & \multirow{2}{*}{$\begin{array}{l}\mathrm{Cu} \\
16\end{array}$} & \multirow{2}{*}{$\begin{array}{l}\mathrm{Fe}^{1} \\
20000\end{array}$} & \multirow{2}{*}{$\begin{array}{l}\mathrm{Pb} \\
31\end{array}$} & \multirow{2}{*}{$\begin{array}{l}\mathrm{Mn}^{1} \\
460\end{array}$} & \multirow{2}{*}{$\begin{array}{l}\mathrm{Ni} \\
16\end{array}$} & \multirow{2}{*}{$\begin{array}{l}\text { Zn } \\
120\end{array}$} \\
\hline SQGs ${ }^{(1)}$ & & LEL & & & & & & & & \\
\hline & & SEL & 10 & 110 & 110 & 40000 & 250 & 1100 & 75 & 820 \\
\hline \multirow[t]{4}{*}{$\begin{array}{l}\text { El- } \\
\text { Tawfiky }\end{array}$} & present result & & $\begin{array}{l}0.421- \\
1.265\end{array}$ & $\begin{array}{l}3.35- \\
8.79\end{array}$ & $\begin{array}{l}4.96- \\
12.68\end{array}$ & $\begin{array}{l}6750- \\
15170\end{array}$ & $\begin{array}{l}4.82- \\
12.9\end{array}$ & $\begin{array}{l}123.16- \\
201.81\end{array}$ & $\begin{array}{l}3.22- \\
5.62\end{array}$ & $\begin{array}{l}16.83- \\
36.36\end{array}$ \\
\hline & Samples < LEL & $\%$ & 43 & 100 & 100 & 100 & 100 & 100 & 100 & 100 \\
\hline & $\begin{array}{l}<\text { SEL samples > } \\
\text { LEL }\end{array}$ & $\%$ & 57 & 0 & 0 & 0 & 0 & 0 & 0 & 0 \\
\hline & Samples > SEL & $\%$ & 0 & 0 & 0 & 0 & 0 & 0 & 0 & 0 \\
\hline \multirow[t]{4}{*}{$\begin{array}{l}\text { El- } \\
\text { Menoufy }\end{array}$} & present result & & $\begin{array}{l}0.724- \\
1.144\end{array}$ & $\begin{array}{l}6.28- \\
11.08\end{array}$ & $\begin{array}{l}9.51- \\
16.51\end{array}$ & $\begin{array}{l}7910- \\
13610\end{array}$ & $\begin{array}{l}7.06- \\
15.9\end{array}$ & $\begin{array}{l}177.2- \\
252.04\end{array}$ & $\begin{array}{l}3.08- \\
6.78\end{array}$ & $20.8-41.66$ \\
\hline & Samples < LEL & $\%$ & 0 & 100 & 85.7 & 100 & 100 & 100 & 100 & 100 \\
\hline & $\begin{array}{l}\text { <SEL samples > } \\
\text { LEL }\end{array}$ & $\%$ & 100 & 0 & 14.3 & 0 & 0 & 0 & 0 & 0 \\
\hline & Samples > SEL & $\%$ & 0 & 0 & 0 & 0 & 0 & 0 & 0 & 0 \\
\hline \multirow[t]{4}{*}{ El-Behary } & present result & & $\begin{array}{l}0.785- \\
3.056\end{array}$ & $\begin{array}{l}10.7- \\
33.5\end{array}$ & $\begin{array}{l}20.02- \\
40.05\end{array}$ & $\begin{array}{l}7120- \\
14900\end{array}$ & $\begin{array}{l}8.14- \\
27.54\end{array}$ & $\begin{array}{l}239.14- \\
422.5\end{array}$ & $\begin{array}{l}2.38- \\
8.54\end{array}$ & $\begin{array}{l}7.12- \\
109.56\end{array}$ \\
\hline & Samples < LEL & $\%$ & 0 & 77.8 & 0 & 100 & 100 & 100 & 100 & 100 \\
\hline & $\begin{array}{l}\text { <SEL samples > } \\
\text { LEL }\end{array}$ & $\%$ & 100 & 22.2 & 100 & 0 & 0 & 0 & 0 & 0 \\
\hline & Samples > SEL & $\%$ & 0 & 0 & 0 & 0 & 0 & 0 & 0 & 0 \\
\hline \multirow[t]{4}{*}{$\begin{array}{l}\text { El- } \\
\text { Nassery }\end{array}$} & present result & & $\begin{array}{l}0.722- \\
1.393\end{array}$ & $\begin{array}{l}6.61- \\
16.54\end{array}$ & $\begin{array}{l}14.68- \\
23.66\end{array}$ & $\begin{array}{l}7360- \\
12130\end{array}$ & $\begin{array}{l}8.11- \\
18.6\end{array}$ & $\begin{array}{l}165.29- \\
245.96\end{array}$ & $\begin{array}{l}2.63- \\
8.57\end{array}$ & $\begin{array}{l}26.33- \\
48.93\end{array}$ \\
\hline & Samples < LEL & $\%$ & 0 & 100 & 25 & 100 & 100 & 100 & 100 & 100 \\
\hline & $\begin{array}{l}\text { <SEL samples > } \\
\text { LEL }\end{array}$ & $\%$ & 100 & 0 & 75 & 0 & 0 & 0 & 0 & 0 \\
\hline & Samples > SEL & $\%$ & 0 & 0 & 0 & 0 & 0 & 0 & 0 & 0 \\
\hline
\end{tabular}

\section{Conclusions}

The Nile River is the main source of water in Egypt, and human civilization has built around its banks since ancient times. The population gathers along it, especially in the study area (the Delta region). A crowded population lives around El-Rayahs and the Damietta and Rosetta branches, which provide fresh water to approximately 40 million people living in the Delta and Alexandria city. However, the Nile River and its canals are exposed to many sources of pollution because of the increase in human activities. Therefore, the present study aims to evaluate the levels and pollution degree of HMs in sediments of the four Rayahs (RT, RM, RB, RN) that can be used as a pollution indicator of the aquatic environment. Our study showed that more than $70 \%$ of El-Rayahs sediments were constituted by sand, with OM ranging from $4.48-16.47 \%$. The absolute maximum values for most metals were found at RB, except Fe and Ni, recorded at RT and RN, respectively, whereas the minimum values were recorded at RT, except Ni recorded at RN with a remarkable increase in metals accumulation northward in all Rayahs. In general, indices data showed that the studied HMs did not cause significant ecological risk except Cd, which represented the highest possible environmental pollution. This finding was confirmed by the results of the SLCA of sediment quality criteria for the (LEL) and SEL. In addition, results of the integrated indices indicated that El-Rayahs were not polluted with HMs, except the northern part of RB (El-Mahmoudia Canal), which is classified as a highly-polluted area. Our research recommends the continuation of environmental monitoring of the four Rayahs and to enforce laws that prevent the dumping of waste in the waterways of the Nile River, especially RB and Rosetta branch (the source of water for El-Mahmoudia Canal).

\section{Declarations}




\section{Data availability}

All data will be available from the corresponding author upon request.

\section{Statements and Declarations}

Funding No funding was received for conducting this study.

Competing Interests The authors have no relevant financial or non-financial interests to disclose

Author contribution Field study and sampling, Seliem M. El-Sayed, Salem G. Salem, Mohamed E. Goher; Sample processing and analysis, Seliem M. El-Sayed, Salem G. Salem, Mohamed H. Abdo, Mohamed E. Goher; writing of the first draft and final text, Seliem M. El-Sayed, Salem G. Salem, Mohamed H. Abdo, Mohamed H.H. Ali, Mohamed E. Goher; review, editing and approving of the final text, Seliem M. El-Sayed, Salem G. Salem, Mohamed H. Abdo, Mohamed H.H. Ali, Mohamed E. Goher.

Ethical Approval Not applicable

Code availability Non applicable.

Consent to participate All authors voluntarily agree to participate in this research study.

Consent to publish All authors voluntarily approved the publication of this research study.

\section{References}

1. Abd El-Aal, F. I., El Sayed, S. M., Attia, M. S., Donia, N. S., Goher, M. E. (2020). Pollution indices and distribution pattern of heavy metals in Qarun Lake water, Egypt. Egyptian Journal of Aquatic Biology \& Fisheries, 24(1): 593-607. DOI: 10.21608/EJABF.2020.75893

2. Abd El-Monsif, A. (2009). Mineral composition and environmental geochemical assessment of bottom sediments of main Nile course from Aswan to Isna "Upper Egypt". Ph. D. Thesis, Department of Geolog., Faculty of Science, Cairo University, 125

3. Abdel-Satar, A. M (2005). Water quality assessment of River Nile from Idfo to Cairo. Egypt. J. Aquat. Res. 31 (2), $200-223$.

4. Abou El-Anwar, E. A (2019). Assessment of heavy metal pollution in soil and bottom sediment of Upper Egypt: comparison study. Bull Natl Res Cent 43, 180. https://doi.org/10.1186/s42269-019-0233-4

5. Abou El-Anwar, E. A, Salman, S., Asmoay, A., Elnazzer, A. (2021). Geochemical, mineralogical and pollution assessment of River Nile sediments at Assiut Governorate, Egypt. Journal of African Earth Sciences 180, 104227. https://doi.org/10.1016/j.jafrearsci.2021.104227

6. Abu El-Enain, F. M, Lotfy, I. M, El-Sorogy, A. S, Wahid EI-Din, A. M. (1997). Sedimentological, mineralogical and geochemical studies on the recent sediments of river Nile, near greater Cairo Egypt. Egyptian Journal of Applied Sciences 12 1028-1051.

7. Ahmed, A., Wal A., Bhattacharya, p., Genuchten, C. (2019). Characteristics of Fe and Mn bearing precipitates generated by Fe(II) and Mn(II) co-oxidation with 02, MnO4 and HOCl in the presence of groundwater ions, Water Research, 161, 505-516, https://doi.org/10.1016/j.watres.2019.06.036.

8. AIP (2017) AIP (American Institute of Physics) Conference Proceedings 1862, 030105, https://doi.org/10.1063/1.4991209 Published Online: 10 July 2017

9. Alagarsamy, R. (2006). Distribution and seasonal variation of trace metals in surface sediments of the Mandovi estuary, west coast of India. Estuarine, Coastal and Shelf Science 67 333-339.

10. Ali, H., Khan, E., Ilahi, I. (2019). Environmental chemistry and ecotoxicology of hazardous heavy metals: Environmental persistence, toxicity, and bioaccumulation. Journal of Chemistry, 2019, 1-14. https://doi.org/10.1155/2019/67303 05

11. Arefin, M. T, Rahman, M. M., Wahid-U-Zzaman, M., Kim, J. E. (2016). Heavy metal contamination in surface water used for irrigation: Functional assessment of the Turag river in Bangladesh. J. Appl. Biol. Chem., 59, 83-90. https://doi.org/10.3839/jabc.2016.015

12. Atgin, R. S., El-Agha, O., Zararsiz, A., Kocatas, A., Parlak, H., Tuncel, G. (2000). Investigation of the sediment pollution in Izmir Bay: trace elements. Spectrochim. Acta B 55 (7), 1151-1164.

13. Bern, C. R., Katie Walton-Day, K., Naftz, D.L. (2019). Improved enrichment factor calculations through principal component analysis: Examples from soils near breccia pipe uranium mines, Arizona, USA, Environmental Pollution, (248): 90-100 https://doi.org/10.1016/j.envpol.2019.01.122.

14. Blaser, P., Zimmermann S., Luster J. (2000). Critical Examination of Trace Element Enrichments and Depletions in Soils: As, Cr, Cu, Ni, Pb, and Zn in Swiss Forest Soils. The Science of the Total Environment, 249: 257-280.

15. Bremner, L. (2021). Sedimentary Ways, Geo Humanities, 7:1, 24-43, https://doi.org/10.1080/2373566X.2020.1799718

16. Cabrera, F., Clemente,.L, Barrientos, D. E. (1999). Heavy metal pollution of soils affected by the guadiamar toxic flood. The Science of the Total Environment 242 (1-3), 117-129.

17. Carver, R. E. (1971). Procedures in Sedimentary Petrology. John Wiley and Sons. Canada, Limited, New York, 653 p.

18. Chatterjee, M., Silva, F. E. V., Sarkar, S. K. (2007). Distribution and Possible Source of Trace Elements in the Sediment Cores of a Tropical Macrotidal Estuary and Their Ecotoxicological Significance. Environment International, 33: 346-356

19. Dianto, A., Ridwansyah, I., Subehi, L. (2020). Organic matter and organic carbon levels in sediments of Lake Maninjau, West Sumatra. IOP Conf. Ser.: Earth Environ. Sci. 535 012030. https://doi:10.1088/1755-1315/535/1/012030 
20. Dinakaran, J., Krishnayya, N. S. R. (2011). Variations in total organic carbon and grain size distribution in ephemeral river sediments in western India. International Journal of Sediment Research, 26 (2): 239-246.

21. El Bouraie, M. M., El Barbary, A. A., Yehia, M. M., Motawea, E. A. (2011). Heavy metal concentrations in surface river water and bed sediments at Nile Delta in Egypt. Suo 61(1) 2010

22. El Sayed, S. M. (2015). Physico - chemical studies of water and sediment quality of Ismailia canal, River Nile, Egypt for its evaluation and protection from some hazard heavy metals Ph.D Thesis. Faculty of science, Al-Azher University, Egypt.

23. El-Amier, Y. A., El-kawy Zahran, M. A., Al-mamory, S. H. (2015). Assessment the Physicochemical Characteristics of Water and Sediment in Rosetta Branch, Egypt. Journal of Water resource and Protection, 7, 1075-1086.

24. El-Kammar, A. M., Ali, B. H., El-Badry, A. M. (2009). Environmental Geochemistry of River Nile Bottom Sediments Between Aswan and Isna, Upper Egypt. Journal of Applied Sciences Research, 5(6): 585-594, 2009

25. Elnazer, A. A., Mostafa, A., Salman, S. A., Seleem, E. M., Al-Gamal, A. G. (2018). Temporal and spatial evaluation of the River nile water quality between Qena and Sohag Cities, Egypt. Bull NRC 42, 3. https://doi.org/10.1186/s42269-018-0005-6.

26. Elsherif, E. A., Badawi, A., Abdelkader, T. (2020). Grain size distribution and environmental implications of Rosetta beach, Mediterranean Sea coast, Egypt, Egyptian Journal of Aquatic Biology \& Fisheries, ISSN 1110-6131. 24(1): 349-370.

27. Faraha,t H. I. (2019). Impact of Drain Effluent on Surficial Sediments in the Mediterranean Coastal Wetland: Sedimentological Characteristics and Metal Pollution Status at Lake Manzala, Egypt. J. Ocean Univ. China (Oceanic and Coastal Sea Research) ISSN 1672-5182, 201918 (4): $834-848$.

https://doi.org/10.1007/s11802-019-3608-0

28. Folk, R. L. (1980). Petrology of Sedimentary Rocks. Hemphills Publ Co, Austin, Texas, p. 170.

29. Forstner, U., Mulle,r G. (1973). Heavy metal accumulation in river sediments: a response to environmental pollution. Geoforum $145: 53-61$.

30. Fu, J., Zhao, C., Luo, Y., Liu, C., Kyzas, G. Z., Luo, Y., Zhao, D., An, Sv, Zhu, H. (2014). Heavy metals in surface sediments of the Jialu River, China: their relations to environmental factors. J Hazard Mater 270:102-109. https://doi.org/10.1016/j.jhazmat.2014.01.044

31. Ghoneim E., Mashaly, J., Gamble, D., Halls, J., AbuBakr, M. (2015). Nile Delta exhibited a spatial reversal in the rates of shoreline retreat on the Rosetta promontory comparing pre-and post-beach protection. Geomorphology, 228: 1-14. Doi:10.1016/j.geomorph.2014.08.021

32. Goher, M. E. (1998). Factors affecting the precipitation and dissolution of some chemical elements in Nile River at Damietta Branch. M. Sci. Thesis, Fac. of Sci. Menofiya Univ. Egypt.

33. Goher, M. E. (2015). Monitoring of present environmental status of El-Rayahs,Nile River, Final Reports prepared to National Institute of Oceanography and Fisheries, Fresh Water and Lakes Division, Cairo, Egypt, $439 \mathrm{p}$.

34. Goher, M. E., Abdo, M. H., Mangood, A. H., Hussein, M. M. (2015). Water quality and potential health risk assessment for consumption of Oreochromis niloticus from El-Bahr El-Pharaony Drain, Egypt. Fresenius Environ. Bull. 24 (11): 3590-3602.

35. Goher, M. E., Ali, M. H. H., El Sayed, S. M. (2019). Heavy metals contents in Nasser Lake and the Nile River, Egypt: An overview, Egyptian Journal of Aquatic Research. 45 (4): 301-312. https://doi.org/10.1016/j.ejar.2019.12.002.

36. Goher, M. E., Farahat, H. I., Abdo, M. H., Salem, G. S. (2014). Metal pollution assessment in the surface sediment of Lake Nasser, Egypt. Egyptian Journal of Aquatic Research. 40(3), 225-233.

37. Goher, M. E., Mangood, A. H., Mousa, I. E., Salem, G. S., Hussein, M. M. (2021). Ecological risk assessment of heavy metal pollution in sediments of Nile River, Egypt. Environ Monit Assess 193:703 https://doi.org/10.1007/s10661-021-09459-3

38. Goldman, C. R. (2009). Micronutrient Elements (Co, Mo, Mn, Zn, Cu), Editor(s): Gene E. Likens, Encyclopedia of Inland Waters, Academic Press, 52-56, https://doi.org/10.1016/B978-012370626-3.00094-6

39. Griffiths, J. C. (1951). Size versus sorting in Caribbean sediments. Jour.Geol. 59, 211-243.

40. Hakanson, L. (1980). An ecological risk index for aquatic pollution control: a sedimentological approach. Water Res. 14, $975-1001$.

41. Hamouda, A., El-Gharabawy, S., Awad, M., Shata, M., Badawi, A. (2014). Characteristic properties of seabed fluvial-marine sediments in front of Damietta promontory, Nile Delta, Egypt. The Egyptian Journal of Aquatic Research, 40(4): 373-383. Doi:10.1016/j.ejar.2014.11.006

42. Hanna, A. (1965). Organic matter in soil. In; Chemistry of soil. 2nd ed. Bear, E.F., Amre. Chem. Soc. Monography Series, N.Y.: $309-317$.

43. Harikumar, P. S., Jishav T. S. (2010). Distribution pattern of trace metal pollutants in the sediments of an urban wetland in the Southwest Coast of India. Int. J. Eng. Sci. Technol. 2 (5), 840-850.

44. Huang, Z., Liu, C., Zhao, X. (2020). Risk assessment of heavy metals in the surface sediment at the drinking water source of the Xiangjiang River in South China. Environ Sci Eur 32, 23 (2020). https://doi.org/10.1186/s12302-020-00305-w

45. Imam, N., El-Sayed, S. M., Goher, M. E. (2020). Risk assessments and spatial distributions of natural radioactivity and heavy metals in Nasser Lake, Egypt. Environ. Sci. Pollut. Res._27:_25475-25493.https://doi.org/10.1007/s11356-020-08918-7

46. Kabata-Pendias, H., Arun, B. M. (2007). Trace Elements from Soil to Human. ISBN-10 3-540-32713-4 Springer Berlin Heidelberg New York.

47. Karak, T., Kutu, F. R., Nath, J. R., Sonar, I., Paul, R. K., Boruah, R. K., Sanyal, S., Sabhapondit, S., Dutta, A. K. (2017). Micronutrients (B, Co, Cu, Fe, Mn, Mo, and Zn) content in made tea (Camellia sinensis L.) and tea infusion with health prospect: A critical review. Crit Rev Food Sci Nutr. 2017 Sep 22;57(14): 2996-3034. DOI: 10.1080/10408398.2015.1083534

48. Kouidri, M., Dali, youcef N., Benabdellah, I. et al., (2016). Enrichment and geoaccumulation of heavy metals and risk assessment of sediments from coast of Ain Temouchent (Algeria). Arab J Geosci 9, 354. https://doi.org/10.1007/s12517-016-2377-y 
49. Lan, X. H., Zhang, Z. X., Li, R. H., Wang, Z. B., Chen, X. H., Hou, F. H. (2011). Geochemical characteristics of trace elements in the marine surface sediments outer Yangtze River Estuary. Geoscience 25 (6), 1066-1077.

50. Lasheen, M. R., Ammar, N. S. (2009). Speciation of some heavy metals in River Nile sediments, Cairo, Egypt. Environmentalist 29, 8-16. https://doi.org/10.1007/s10669-008-9175-3

51. Lenntech, (2022). Nickel and water: reaction mechanisms, environmental impact and health effects. Available on line https://www.lenntech.com/periodic/water/nickel/nickel-and-water.htm\#ixzz7fNPwoUdX, last visit, 20/9/2022.

52. Lide, D. R. (2008). CRC Handbook of Chemistry and Physics, 88th edition 2007-2008. Boca Raton, Florida: Taylor \& Francis Group, p. 4-71

53. Liu, W. H., Zhao, J. Z., Ouyang, Z. Y. (2005). Impacts of Sewage Irrigation on Heavy Metal Distribution and Contamination in Beijing, China. Environment International, 31: 805-812

54. Long, E. R., Morgan, L. G. (1991). The potential for biological effects of sediment-sorbed contaminants tested in the National Status and Trends Program. NOAA Technical Memorandum NOS OMA 52, National Oceanic and Atmospheric Administration, Seattle, WA, 175 pp 1 appendices.

55. Masoud, M. S., Fahmy, M. A., Ali, A. E. Mohamed, E. A. (2011). Heavy metal speciation and their accumulation in sediments of Lake Burullus, Egypt. African Journal of Environmental Science and Technology 5(4), 280-298.

56. Mateo-Sagasta, J., Zadeh, S. M., Turral, H. (2017). Water pollution from agriculture: a global review. Executive summary [Internet]. Rome, Italy: Food and Agriculture Organization of the United Nations (FAO); Colombo, Sri Lanka: International Water Management Institute (IWMI). http://www.fao.org/3/ai7754e.pdf

57. Mohiuddin, K. M., Zakir, H. M., Otomo, K., Sharmin, S., Shikazono, N. (2010). Geochemical distribution of trace metal pollutants in water and sediments of downstream of an urban river. Int. J.Environ. Sci. Technol. 7 (1), 17-28.

58. Mostafa, A., Salman, S. A., Seleem, M. S., Elnazer, A. A., Al-Gamal, A. G., El-Taher, A., Mansour, H. (2019). Quality assessment of River Nile sediment between Qena and Sohag Cities, Egypt. Jour Environ Sci Tech 12 (3), 117-124. https://doi.org/10.3923/jest.2019.117.124.

59. Mucha, A. P., Vasconcelos M. T. S. D., Bordalo A. A. (2003). Macrobenthic community in the Doura estuary: relations with trace metals and natural sediment characteristics. Environ. Pollut. 121, 169-180.

60. Muller, G. (1969). Index of geoaccumulation in sediments of the Rhine River. Geol. J. 2: 109-118.

61. Muller, G. (1981). Die schwermetallbelstung der sedimente des neckars und seiner nebenflusse: eine estandsaufnahme. Chem. Zeitung 105,157-164.

62. Nasir, U., Saeed, M., Yousif, S. (2021). Environmental Impact Assessment of Heavy Metals in Surface Disposed Drilling Waste. Journal of Geoscience and Environment Protection, 9, 227-238. doi: 10.4236/gep.2021.99012.

63. Nielsen, F. (2021). Nickel. Adv Nutr. 1;12(1):281-282. doi: 10.1093/advances/nmaa154. PMID: 33307548; PMCID: PMC7849985.

64. Ottosen, L. M., Lepkova, K., Martin, K. (2006). Comparison of electrodialytic removal of Cu from spiked kaolinite, spiked soil and industrially polluted soil. Journal of Hazardous Materials 137 113-120.

65. Paul, D. (2017). Research on heavy metal pollution of river Ganga: a review. Ann. Agrar. Sci. 15, 278-286. https://doi.org/10.1016/j.aasci.2017.04.001.

66. Persaud, D. R., Jaagumagi, R., Hayton, A. (1993). Guidelines for the Protection and Management of Aquatic Sediments in Ontario. Standards Development Branch. Ontario Ministry of Environment and Energy, Toronto, Canada, $27 \mathrm{pp}$.

67. Prashanth L., Kattapagari K. K., Chitturi R. T., Baddam,V. R. (2015). Prasad LK. A review on role of essential trace elements in health and disease. J NTR Univ Health Sci;4:75-85. DOI: 10.4103/2277-8632.158577

68. Qu, X., Ren, Z., Zhang, M. et al., (2017). Sediment heavy metals and benthic diversities in Hun-Tai River, northeast of China. Environ Sci Pollut Res 24 , 10662-10673. https://doi.org/10.1007/s11356-017-8642-0

69. Raja, P, Achyuthan, H, Geethanjali, K, Chopra, S. (2018). Late Pleistocene Paleoflood Deposits Identified by Grain Size Signatures, Parsons Valley Lake, Nilgiris, Tamil Nadu. J Geol Soc India 91, 547-553. https://doi.org/10.1007/s12594-018-0903-0

70. RAMP (2021). Sediment quality, prepared by Regional Aquatics Monitoring Program (RAMP), available online http://www.rampalberta.org/ramp/design+and+monitoring/components/sediment.aspx. Last visit 12 October 2021

71. Salem, G. S. (2011). Sedimentary facies and geochemical studies on the recent bottom sediment of River Nile from Aswan to Cairo, Egypt. Ph.D. Thesis, Faculty of Science, Banha University, Egypt.

72. Salem, G. S. and Lotfy, M. H. (2017). Heavy Mineral Distribution and Geochemical Stuides Of Damiatta And Rosseta Nile Branches, Egypt. International Journal of Geology, Earth \& invironmental Sciences ISSN: $2277-2081$.

73. SCDHEC (2020). A review of lead in surface waters Prepared by The Bureau of Water South Carolina Department of Health and Environmental Control, SCDHEC Technical Document Number: 003-2020, Available at: https://www.scdhec.gov/sites/default/files/media/document/final_Pb_report_w_annexes_jan_2020.pdf

74. Shyleshchandran, M. N., Mohan, M., Ramasamy, E. V. (2018). Risk assessment of heavy metals in Vembanad Lake sediments (south-west coast of India), based on acid-volatile sulfide (AVS)-simultaneously extracted metal (SEM) approach. Environ Sci Pollut Res 25, 7333-7345. https://doi.org/10.1007/s11356-017-0997-8

75. SLC/MENVIQ (ST. Lawrence Centre and Ministère de L'Environnement du Québec). (1992). Interim Criteria for Quality Assessment of St. Lawrence River Sediment. Environment Canada, Conservation and Protection, Quebec Region. Montréal

76. Smith, S. L., MacDonald, D. D., Keenleyside K. A., Ingersoll C. G., Field J. (1996). A preliminary evaluation of sediment quality assessment values for freshwater ecosystems. J Great Lakes Res 22:624-638. 
77. Stanley, J. D., Goddio, F., Jorstad, T. F., Schnepp, G. (2004). Submergence of ancient Greek cities off Egypt's Nile Delta-A cautionary tale. GSA TODAY, 14(1): 4-10. Doi:10.1130/1052 5173(2004)014<4:SOAGCO > 2.0.CO;2

78. Sutherland, R. A. (2000). Bed sediment-associated trace metals in an urban stream, Oahu, Hawaii. Environ. Geol. 39, 611-627.

79. Szarek-Gwiazda, E., Czaplicka-Kotas, A., Szalinska, E. (2011). Background concentrations of nickel in the sediments of the carpathian dam reservoirs (Southem Poland), Clean - Soil Air Water, 39 (2011) 368-375. https://doi.org/10.1002/clen.201000114

80. Talab A. S., Goher M. E., Ghannam H. E., Abdo M. H. (2016). Chemical compositions and heavy metal contents of Oreochromis niloticus from the main irrigated canals (Rayahs) of Nile Delta. Egyptian Journal of Aquatic Research, 42, 23-31.

81. Tiomo, I. F., Tematiov P., Momo, M. N., Happi, F. D., Guimapi, N. T., Tchaptchet, W. C. T. (2021). Mineralogical and geochemical evolution of pre-lateritic soil profiles over schist basement of the Lom series (Bétaré-Oya, East Cameroon): Implication to rock weathering and lithologic constraints on trace elements fractionation, Journal of African Earth Sciences, 176, 104133, https://doi.org/10.1016/j.jafrearsci.2021.104133.

82. Tomlinson, D. C., Wilson, J. G., Harris, C. R., Jeffrey, D. W. (1980). Problems in the assessment of heavy-metal levels in stuaries and the formation of a pollution index. Helgoland Mar. Res. 33, 566-575.

83. Tumolo, M., Ancona, V., De Paola, D., Losacco, D., Campanalev C., Massarelli, C., Uricchio, V. F. (2020). Chromium Pollution in European Water, Sources, Health Risk, and Remediation Strategies: An Overview. International journal of environmental research and public health, $17(15), 5438$.

https://doi.org/10.3390/ijerph17155438

84. Turekian, K. K., Wedepohl, K. H. (1961). Distribution of the elements in some major units of the Earth's crust. Geol. Soc. Am. 72, 175-192.

85. UNCSD (2010). The United Nations Conference on Sustainable Development. New York, USA, May, 2010

86. USEPA (United States Environmental Protection Agency) (1996a). Microwave assisted acid digestion of siliceous and organically based matrices. SW-846 EPA Method 3052. Test Methods for Evaluating Solid Waste. 3rd Update. Washington, DC: US Environmental Protection Agency.

87. USEPA (United States Environmental Protection Agency) (1996b) Calculation and evaluation of sediment effect concentrations for the amphipod Hyalella azteca and the midge Chironomus riparius. EPA 905-R96-008, Great Lakes National Program Office,Region V, Chicago, IL

88. USEPA (United States Environmental Protection Agency) (1997). The incidence and severity of sediment contamination in surface waters of the United States. Volume 1: National sediment quality survey. EPA 823-R-97-006, Office of Science and Technology, Washington, DC.

89. Wani, A. L., Ara A., Usmani J. A. (2015). Lead toxicity: a review. Interdisciplinary toxicology, 8(2), 55-64. https://doi.org/10.1515/intox-2015-0009

90. Welte, D.H. (1969). Organic Matter in Sediments. In: Eglinton, G., Murphy, M.T.J. (eds) Organic Geochemistry. Springer, Berlin, Heidelberg. https://doi.org/10.1007/978-3-642-87734-6_12

91. WWAP (2017). The United Nations World Water Development Report 2017: Wastewater, the untapped resource. United Nations World Water Assessment Programme (WWAP). Paris, United Nations Educational, Scientific and Cultural Organization. https://www.unido.org/sites/default/files/2017-

03/UN_World_Water_Development_Report_-_Full_0.pdf

92. Yuana, S., Tanga, H., Xiaoa, Y., Xiab, Y., Melchingcv C., Lia, Z. (2019). Phosphorus contamination of the surface sediment at a river confluence. J. Hydrol. $573,568-580$.

93. Zakir, H. M., Shikazono, N., Otomo, K. (2008). Geochemical distribution of trace metals and assessment of anthropogenic pollution in sediments of Old Nakagawa River, Tokyo. Jpn. Am. J. Environ. Sci. 4 (6), 661-672.

94. Zhang, J., Liu, C. L. (2002). Riverine composition and estuarine geochemistry of particulate metals in China-Weathering features,anthropogenic impact and chemical fluxes. Estuar. Coast. Shelf Sci.54 (6), 1051-1070.

95. Zhang, L. P., Ye, X., Feng, H. (2007). Heavy Metal Contamination in Western Xiamen Bay Sediments and Its Vicinity, China. Marine Pollution Bulletin, 54: 974-982.

\section{Figures}




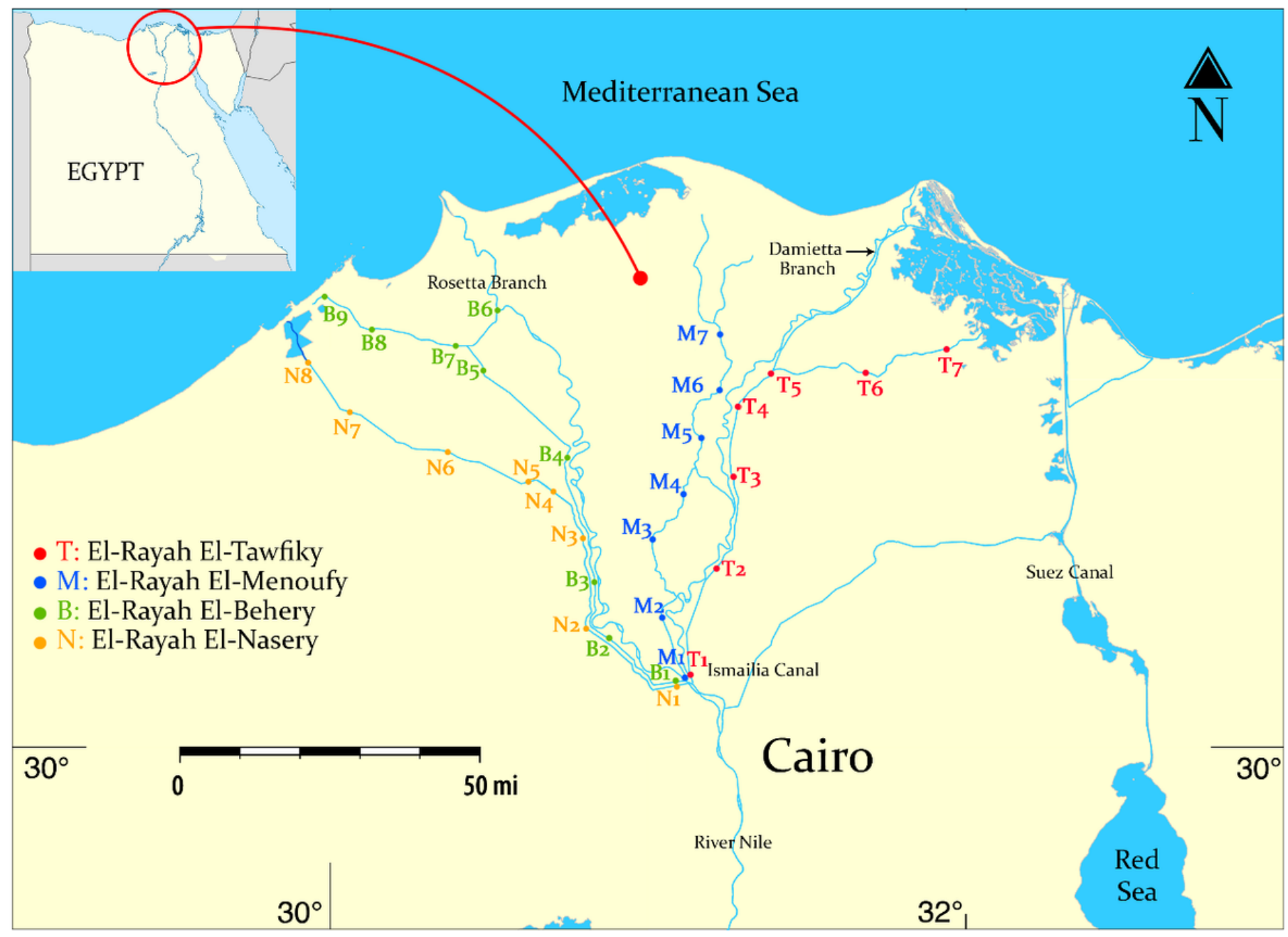

Figure 1

Map of the study area indicating the selecting sites

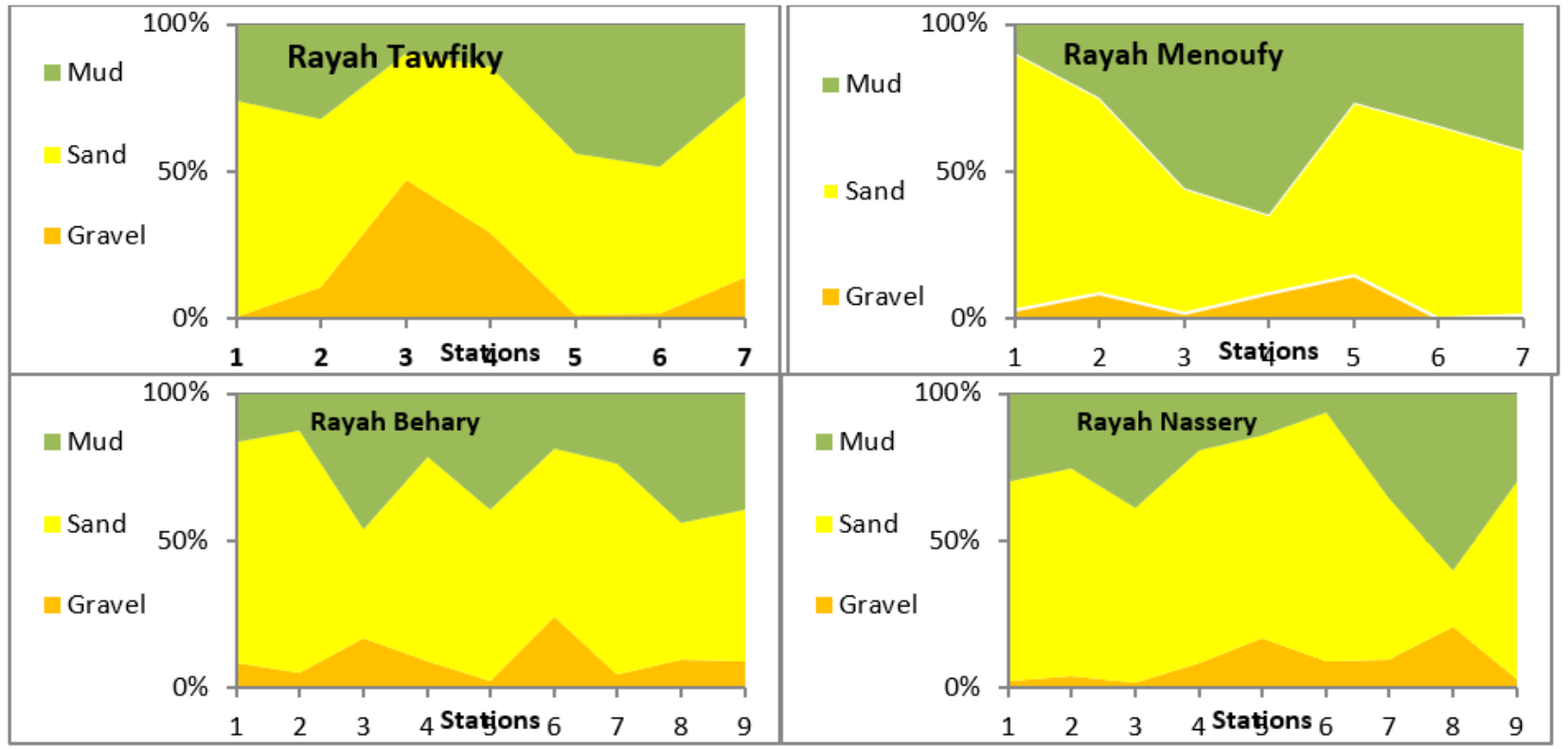

Figure 2

Horizontal distribution of grain size of the four Rayahs sediments. 


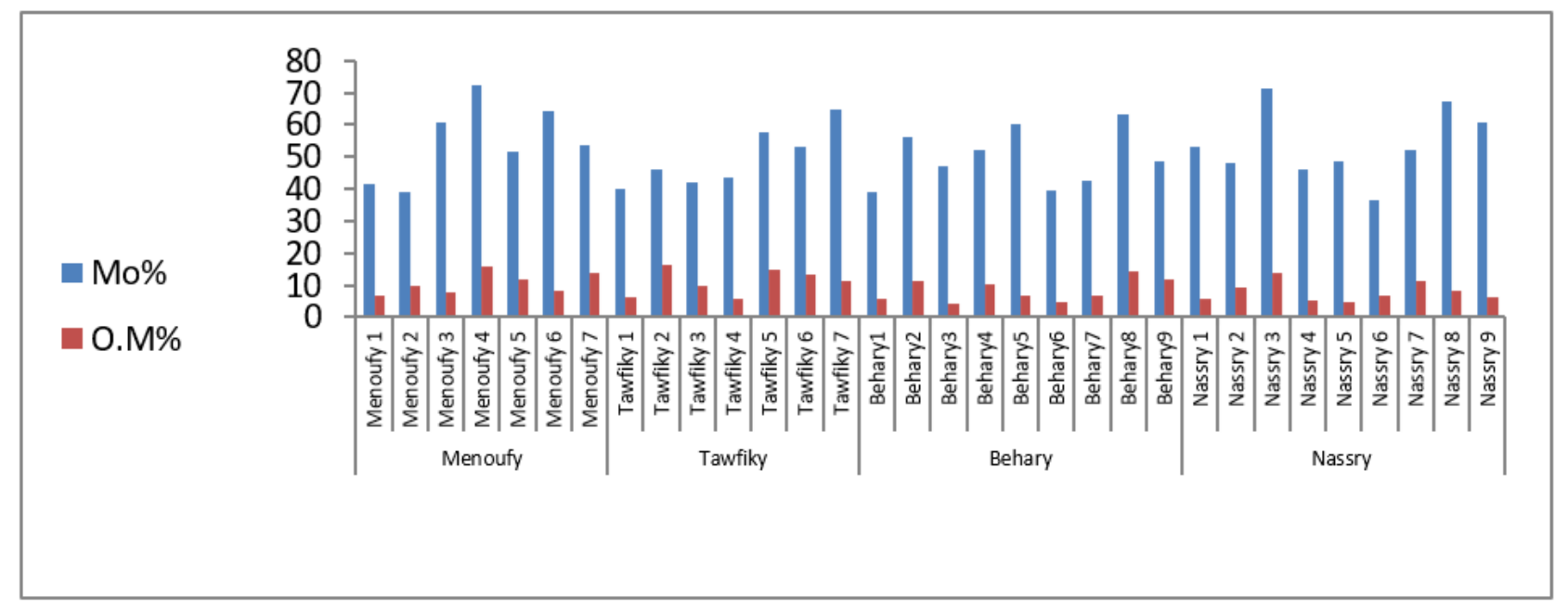

Figure 3

Organic matter and Moisture of the studied trace metals of the four Rayahs sediments
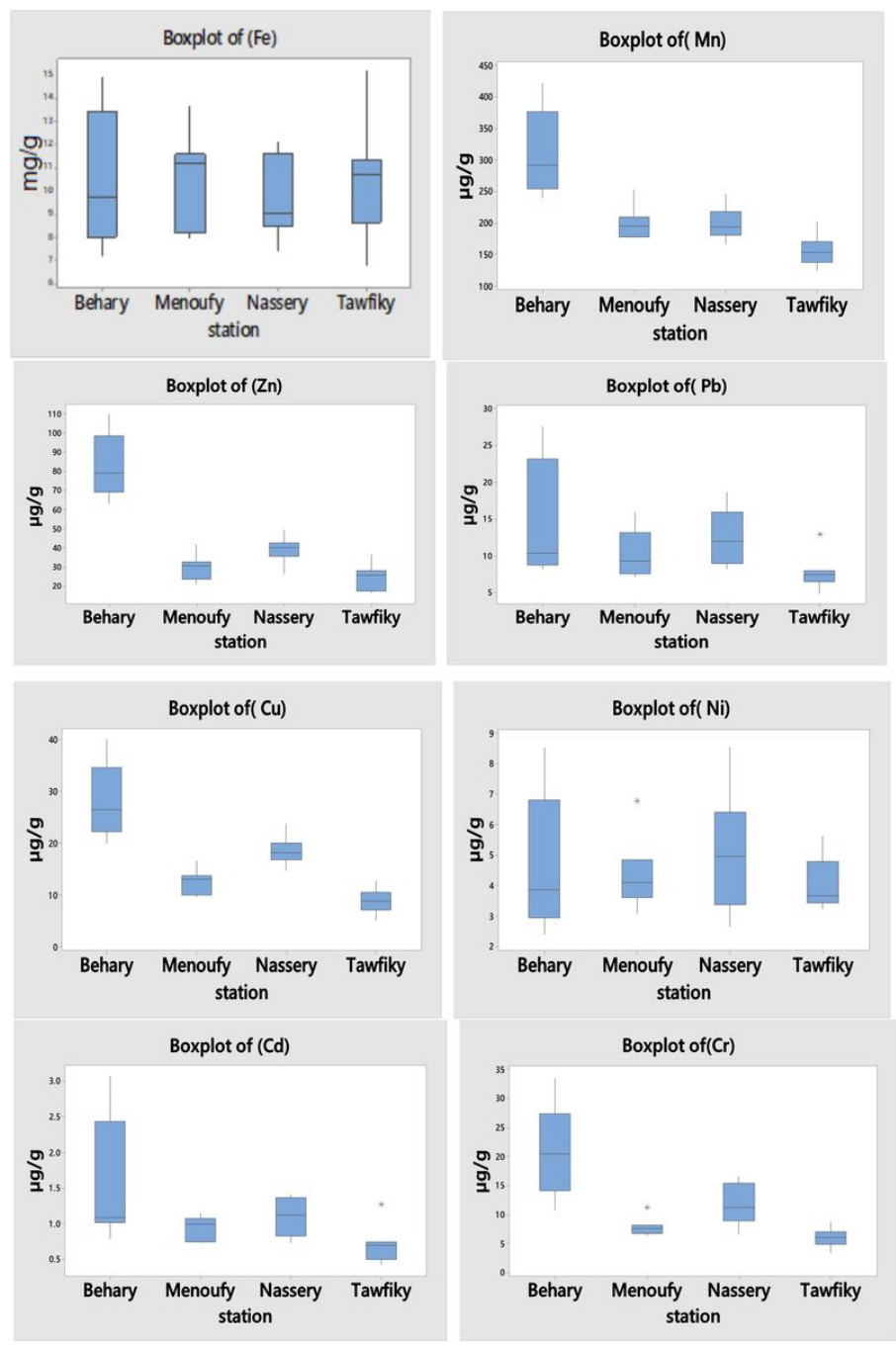

Figure 4

Box plot of the studied trace metals in the sediment of the four Rayahs. 